ص ص[Or-ra]

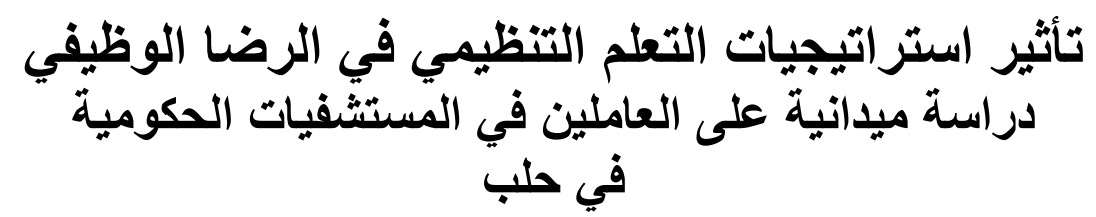

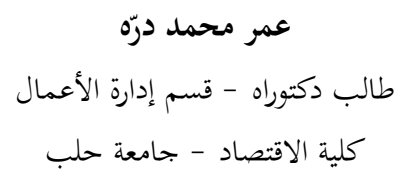

amori999@yahoo.com

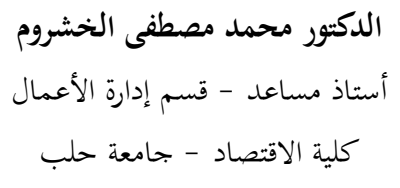

kachroum1949@yahoo.com

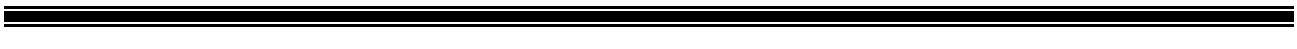

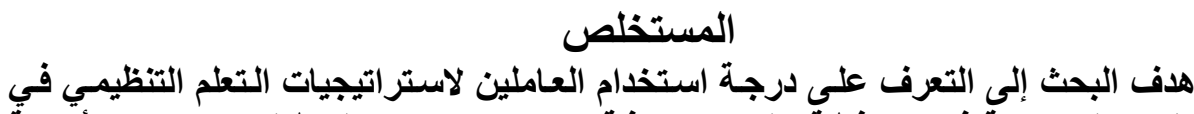

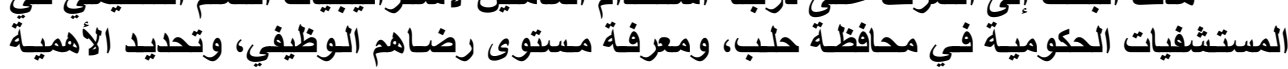

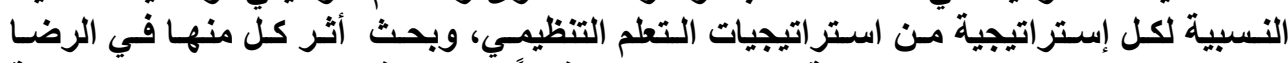

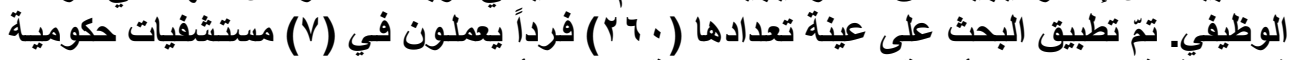

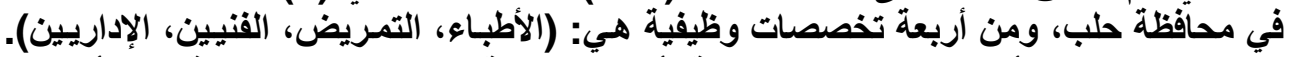

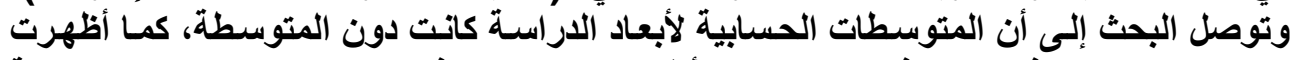

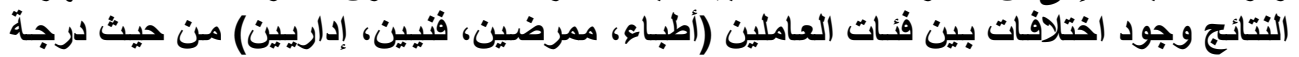

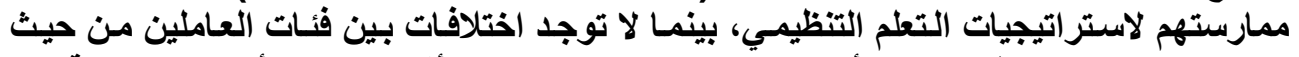

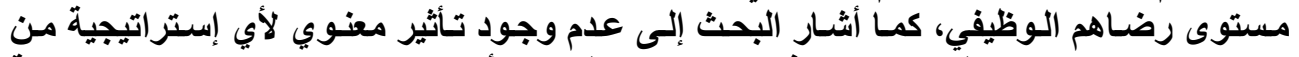

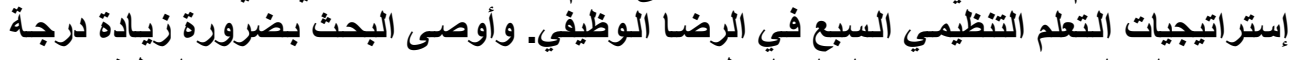
استخدام العاملين لإستراتيجيات التعلم التنظيمي والاهتمام بتحسين مستوفي التوى رضاهم الوظيفي.

الكلمات المفتاحية: استراتيجيات التطلم التظيمي، الرضا الوظيفي، المستثفيات.
}

\title{
The Effect of Organizational Learning Strategies on Job Satisfaction Field Study at Workers in Government Hospitals in Aleppo
}

\author{
Mohammad M. Alkhshroum (PhD) \\ Associate Professor \\ Department of Business Administration \\ Aleppo University
}

Omar M. Durrah

Doctoral Student

Department Business Administration Aleppo University

\section{Abstract}

This study aims to show the degree practice of the workers to the organizational learning strategies in government hospitals in Aleppo governorate, and identify the level of their job satisfactions. The relative importance for each strategy of the foundation learning

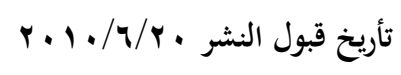

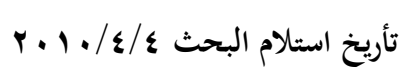


strategies have been determined, and studying the impact each strategy on the job satisfaction. The study was applied on sample formed (260) persons which work in (7) hospitals in Aleppo from (4) functional specializations: (doctors, nurses, technicians, administrators). The results of the study can be summarized as follows: the means of dimensions of the study was less from middle, and there are differences between categories of workers (doctors, nurses, technical's, administrators) in degree their practice to organizational learning strategies, while there are no differences between categories of workers in level their job satisfaction, and there are no significant impact to foundation learning strategies on job satisfaction. The study recommends an agent increase degree practice the workers to organizational learning strategies, and care with improvement level their job satisfaction.

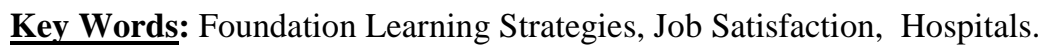

المقدمة

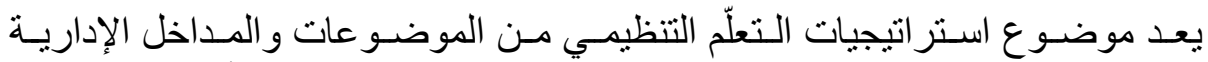

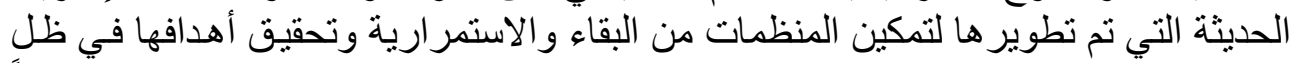

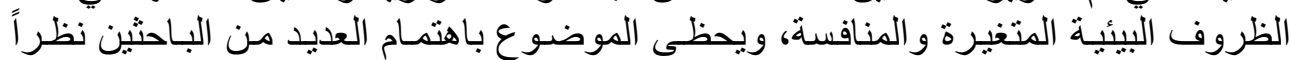

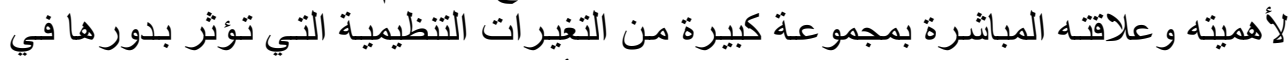

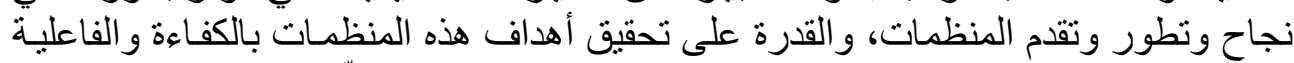

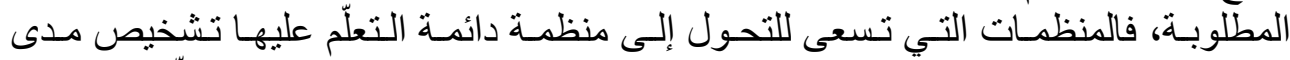
جاهزيتها للتعلم، وذلك من خلال قياس مدى تبنيها وتطبيقها لاستر اتيجيات التعلّم المتنوعـة.

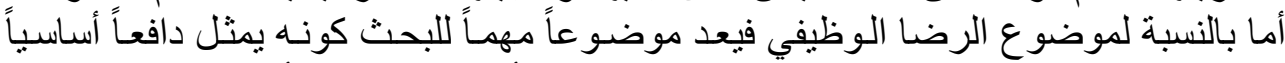

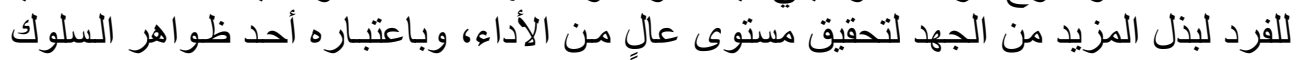

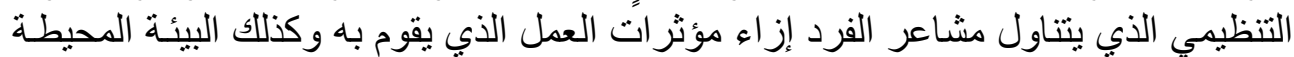

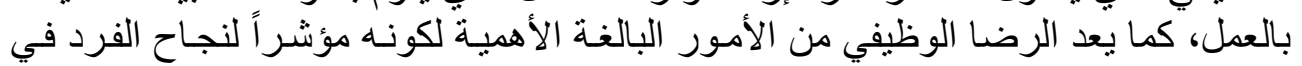
مختلف جو انب حياته.

الأهميـة النظريـة: تعد اسـتر اتيجيات التعلم التنظيمي من الموضـوعات الحديثة التي دخلت

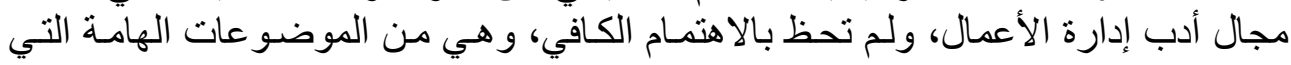

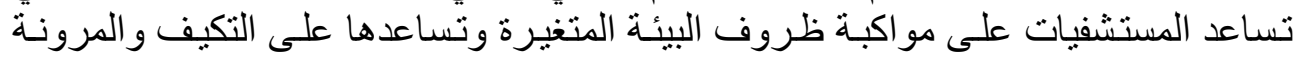

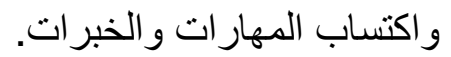

\section{الأهمية التطبيقية: وتنبع من خلال:}

ا ـ كون المستشفيات من المنشآت الخدميـة المحوريـة في في تقديم الخدمات الصنية الصحية و الطبيـة للمو اطنين ، فضلاً عن أنها تتبح فرص التدريب و التطبيتق والاستخدام و البحث: للأطبـاء و الباحثين. ץ. الحاجة لتطبيق هذا المفهوم في البيئة العربية على وجه العدوم وفي البيئة السورية على وجه الخصوص. ب. ندرة الدر اسات و الأبحاث التطبيقية لهذا المفهوم و غموضه في القطاع الصحي. 


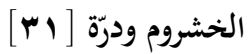

ا. التعرّف على استر اتيجيات التعلم التنظيمي بالمستشفيات محل البحث وتحديد الأهميـة النسبية لكل إستر اتيجية من هذه الاستر اتيجيات.

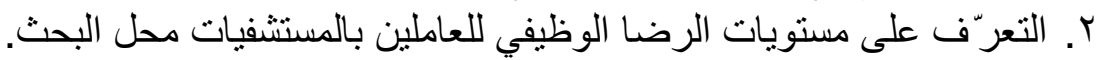

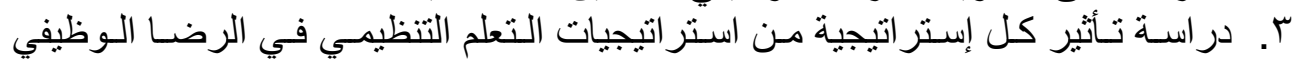
للعاملين في المستشفيات محل البحث.

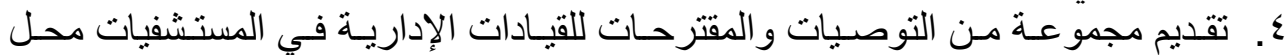

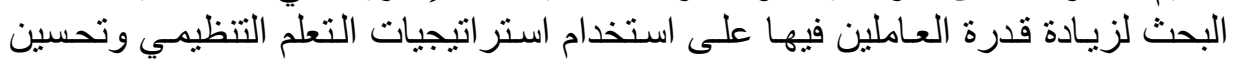
مستوى رضاهم الوظيفي.

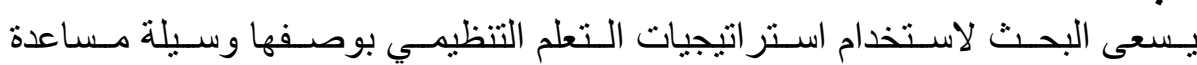

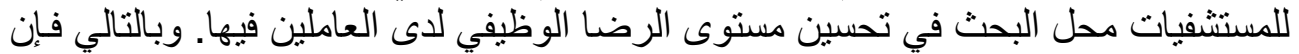

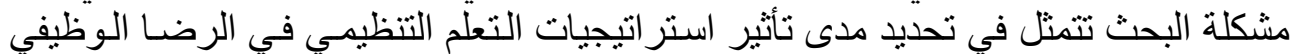

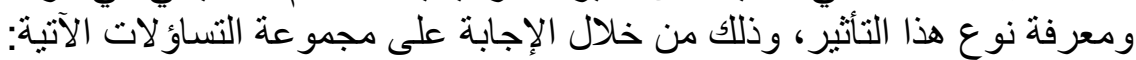

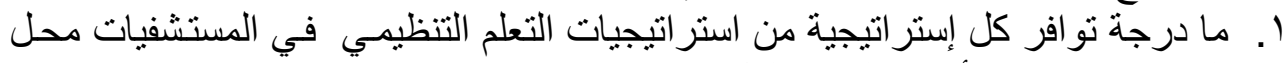

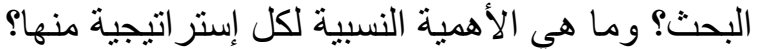

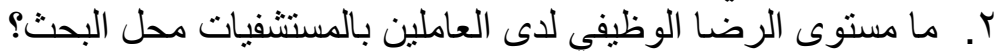

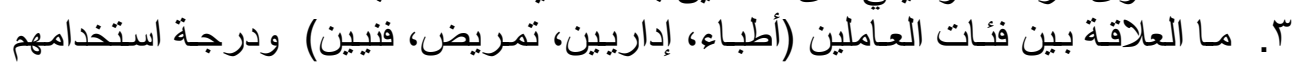

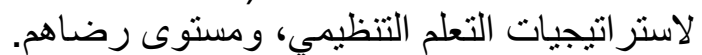

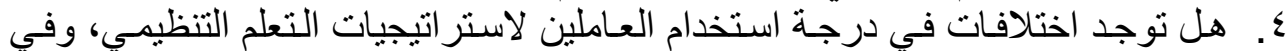

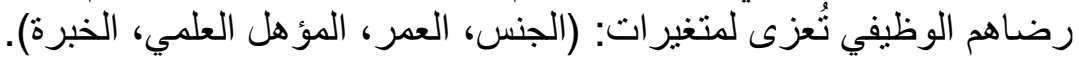

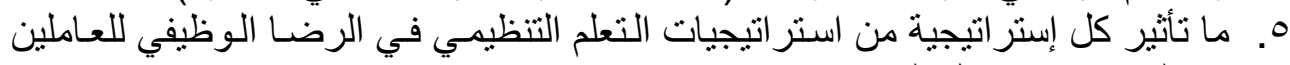

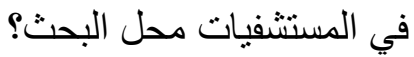

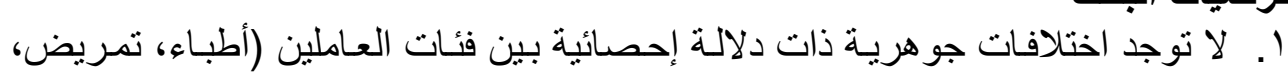

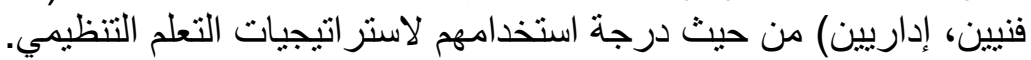

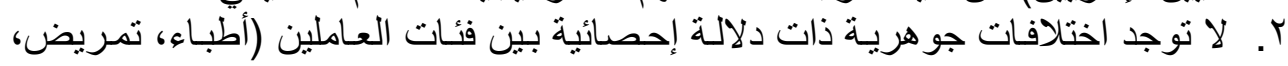

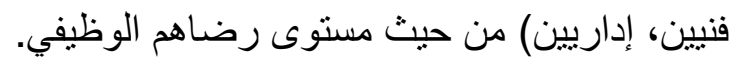

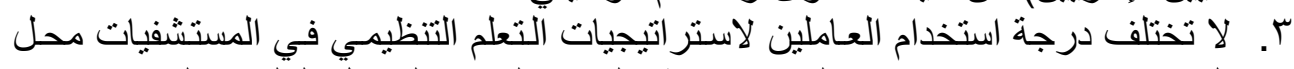

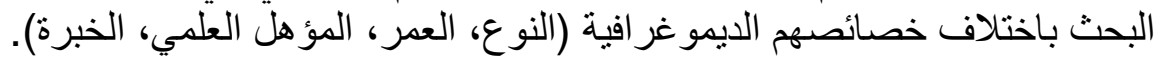

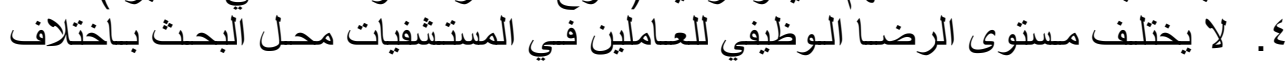

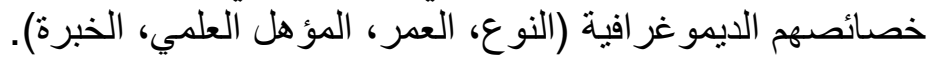

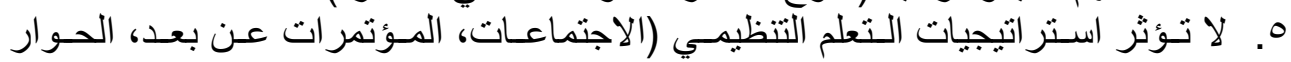

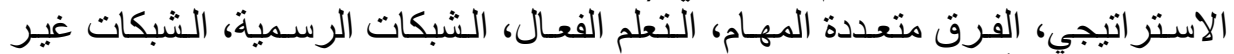

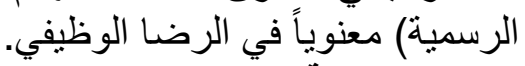
التعريفات الإجرائية 
ا. استراتيجيات التعلم التظيمي: يقصد بها تللك الطرائق التي تقوم المنظمات بتطبيقها

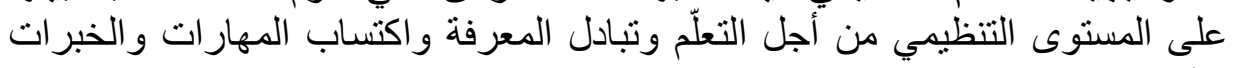

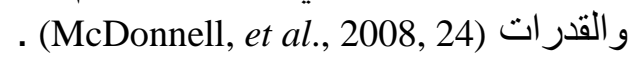
r. الرضا الوظيفي: يقصد بـه القناعات والاستجابات النفسية و العاطفية السلبية والإيجابية

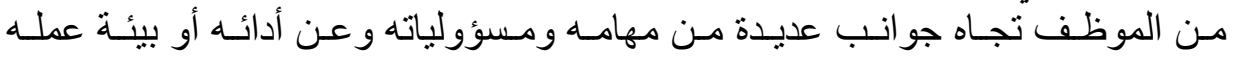

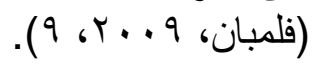

أنموذج البحث

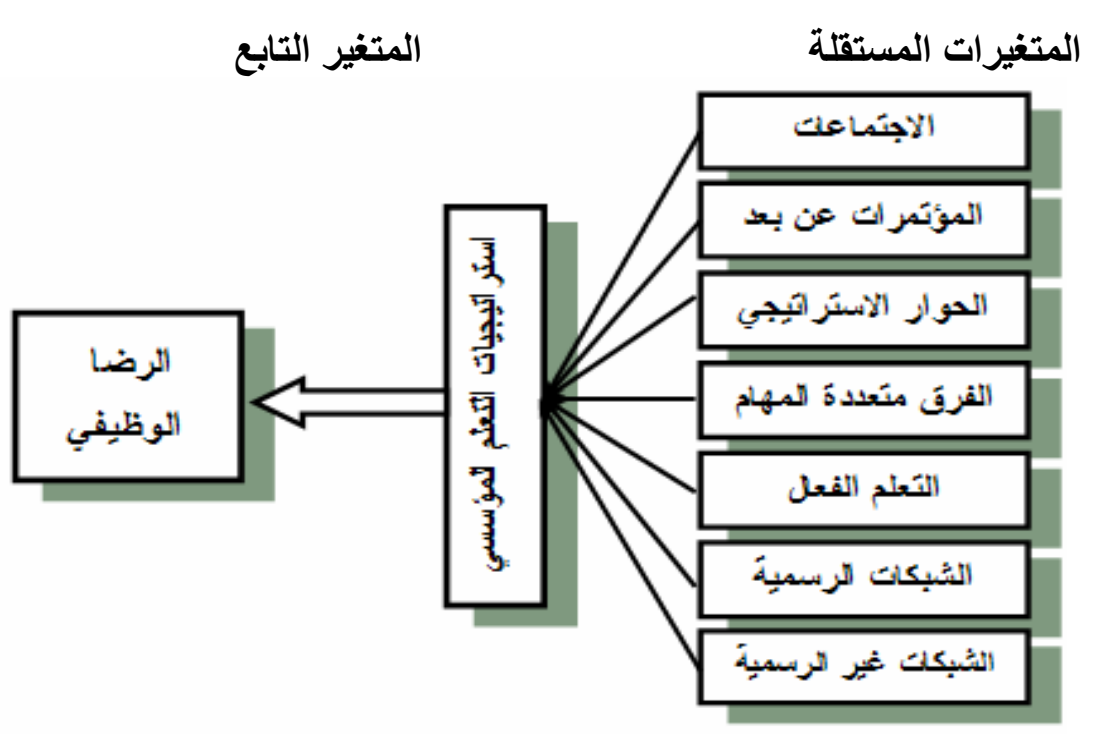

منهجية البحث

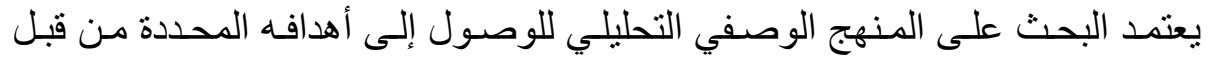

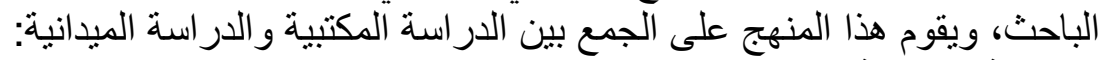

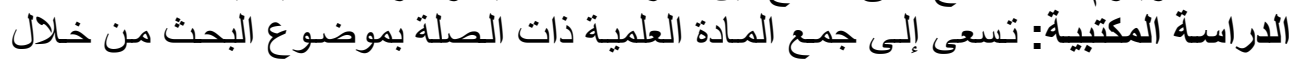

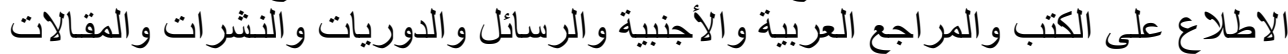

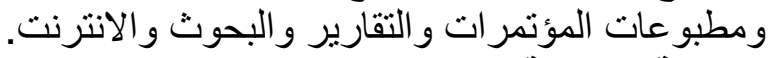

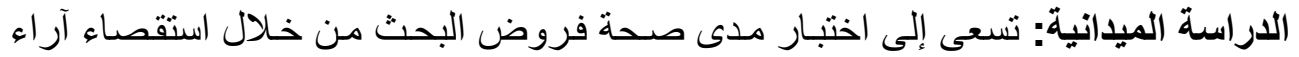

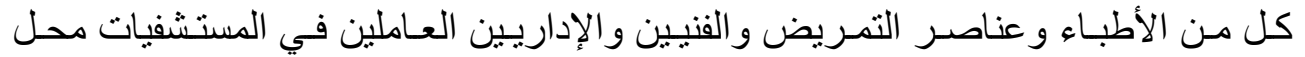
البحث، وذللك من خلال جمع البيانات بو اسطة الاستبانة ومن ثم تفريغها وتحليلها.

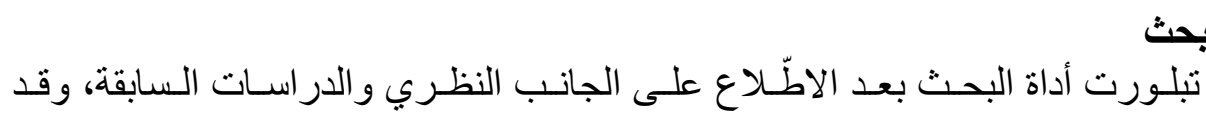

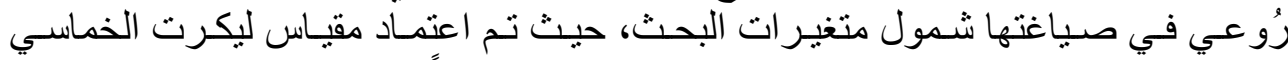

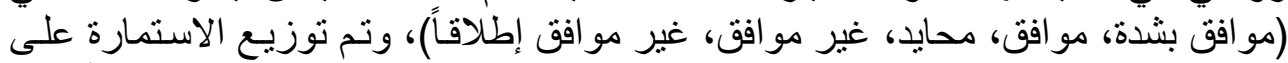

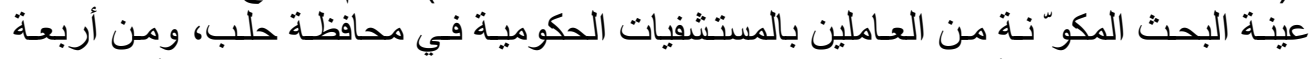
تخصصات وظيفية (أطباء، تمريضة فيضة فنيين، إداريين) وتتكون الاستبانة من ثناثة أقسام: 


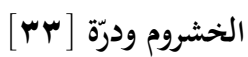

القسم الأول: يشمل على المتغير ات الديموغر افية، وتمّ قياسها باستخدام ه أسئلة.

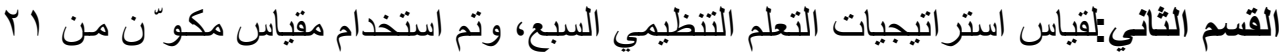
عبارة بو اقع ثلاث عبار اتلثيات لكل إستر اتيجية.

القسم الثالث: لقياس الرضا الوثيلفي، وتم استخدام مقياس مكوّ" ن من ع ا عبارة.

صدق أداة البحث وثباتها

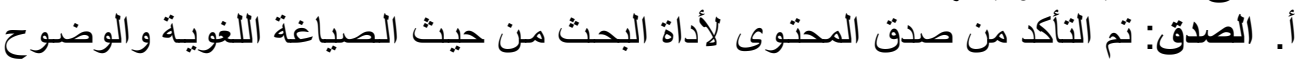

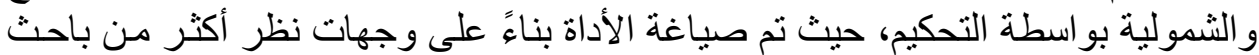

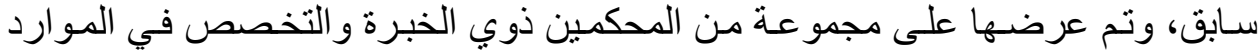

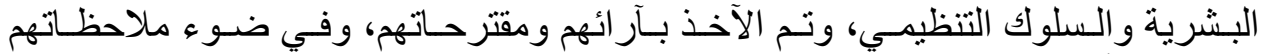

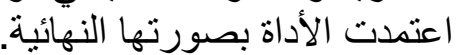

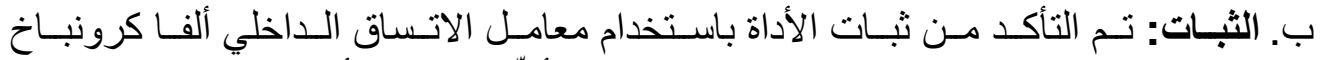

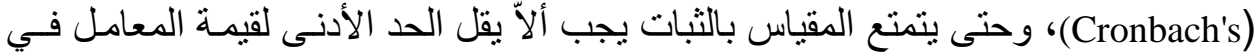

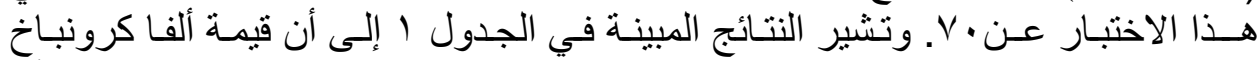

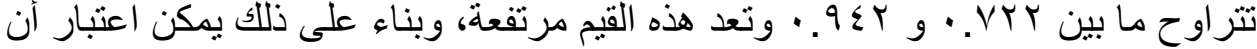
المقاييس المستخدمة في هذا البحث تتسم بالثبات الداخلي لعبار اتها.

\begin{tabular}{|c|c|c|c|}
\hline \multicolumn{4}{|c|}{ 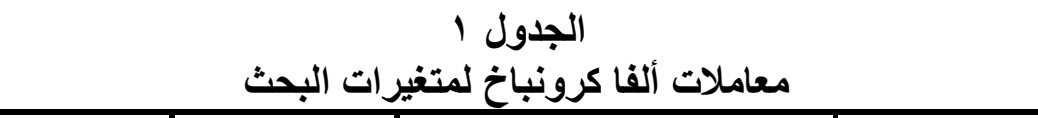 } \\
\hline العبارات عدد & معامل الثبات & الإستراتيجية & المتغيرات \\
\hline$r$ &.$V Y Y$ & الاجتماعات & \multirow{8}{*}{ استر اتيجيات التظميمي } \\
\hline$r$ &.$\wedge \vee 0$ & المؤتمر ات عن بعد & \\
\hline$r$ &..$\wedge 0 \mu$ & الحوار الاستر اتيجي & \\
\hline$r$ & $\cdot . \wedge \leq \mu$ & الفرق متعددة المهام & \\
\hline$r$ &. .119 & التعلم الفعال & \\
\hline$r$ & $\because \wedge \vee$. & الشبكات الرسمية & \\
\hline$r$ &.$\wedge \cdot 1$ & الثبكات غير الرسمية & \\
\hline YI & $. .9 \leqslant Y$ & جميع الاستر اتيجيات & \\
\hline $1 \varepsilon$ & $\cdot . \wedge \wedge \vee$ & \multicolumn{2}{|c|}{ الرضا الوظيفي } \\
\hline
\end{tabular}




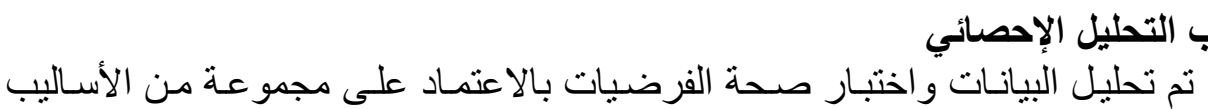

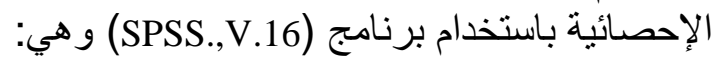

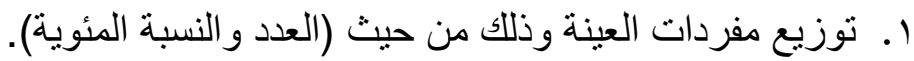

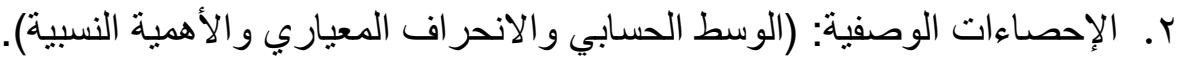

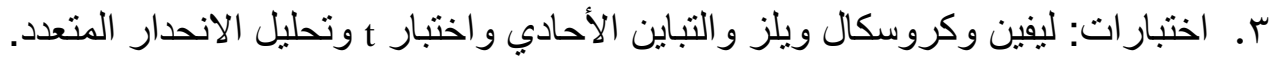

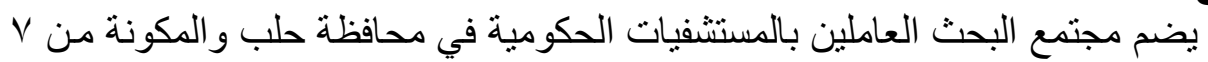

\section{مجتمع البحث}

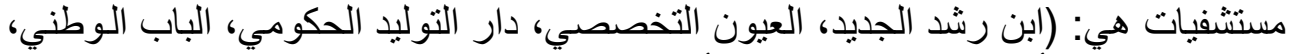

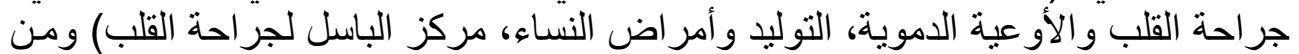

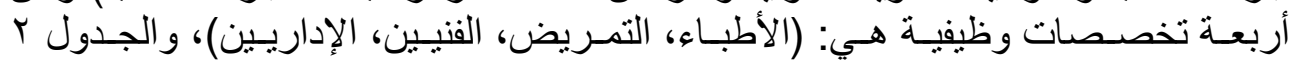
يوضح مجتمع البحث.

\begin{tabular}{|c|c|c|c|c|c|}
\hline \multirow{3}{*}{ المجموع } & \multicolumn{4}{|c|}{ مجتمع البحول r } & \multirow{3}{*}{ المستثفى } \\
\hline & \multicolumn{4}{|c|}{ عدد العاملين من كل وظيفة } & \\
\hline & القنيين & التمريض & الإداريين & الأطباء & \\
\hline$T \cdot V$ & $\varepsilon$ & $7 \varepsilon$ & TY & 91 & ابن رشد الجديد \\
\hline $1 \leq r$ & rq & Or & IV & $\varepsilon V$ & العيون التخصصي \\
\hline TrV & 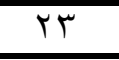 & $\Lambda \Lambda$ & $r \varepsilon$ & $9 Y$ & دار التوليد الحكومي \\
\hline$r \leqslant \Lambda$ & $\varepsilon \varepsilon$ & $\sqrt{99}$ & rq & 97 & الباب الوطني \\
\hline $1 \wedge$. & $\varepsilon 0$ & Vo & $r \cdot$ & $\varepsilon \cdot$ & جراحة القلب و الأو عية الدموية \\
\hline$r \cdot \varepsilon$ & $\varepsilon \varepsilon$ & $1 \pi r$ & $r \varepsilon$ & $1 \cdot \varepsilon$ & التوليد و أمر اض النساء \\
\hline rqY & $T V$ & Tro & ro & 70 & مركز الباسل لجر احة القلب \\
\hline $17 \ldots$ & rA9 & 710 & 171 & oro & المجموع \\
\hline
\end{tabular}

تمّ اختيار عينة البحث على وفق المعادلة الآتية:

$$
\mathrm{N}=\frac{\mathrm{P}(1-\mathrm{P})}{\frac{\mathrm{P}(1-\mathrm{P})}{(\mathrm{N} 1)}+\frac{(\mathrm{D})^{2}}{(\mathrm{D} \cdot \mathrm{M})^{2}}}
$$

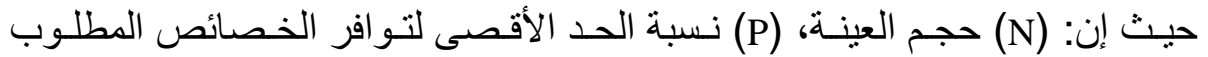

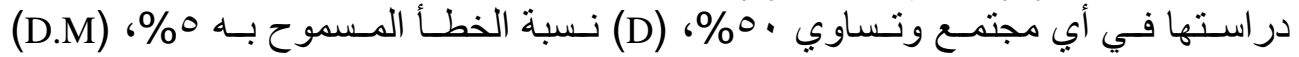

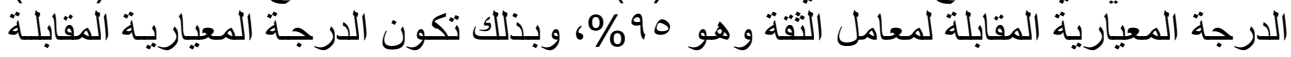

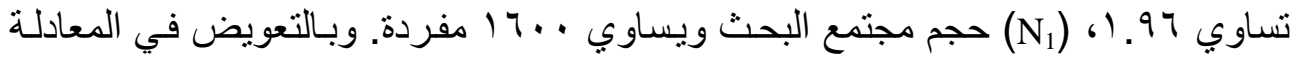
السابقة يكون حجم العينة ـ الب مفردات. 


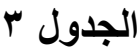

توزيع مفردات عينة البحث

\begin{tabular}{|c|c|c|c|c|c|}
\hline \multirow{2}{*}{ المجموع } & \multicolumn{4}{|c|}{ عدد العاملين من كل وظيفة } & \multirow{2}{*}{ المستثفى } \\
\hline & الفنيين & التمريض & الإداريين & الأطباء & \\
\hline$r \varepsilon$ & 7 & 11 & r & 10 & ابن رشد الجديد \\
\hline Tr & $\varepsilon$ & 9 & $r$ & $\mathrm{~V}$ & العيون التخصصي \\
\hline$r v$ & $\varepsilon$ & $1 \varepsilon$ & $\varepsilon$ & 10 & دار التوليد الحكومي \\
\hline$\varepsilon 1$ & V & $1 \pi$ & 0 & 17 & الباب الوطني \\
\hline rq & $\Lambda$ & IT & $r$ & 7 & جر احة القلب و الأو عية الدموية \\
\hline$\varepsilon 9$ & $\mathrm{~V}$ & YI & $\varepsilon$ & IV & التوليد و أمر اض النساء \\
\hline$\varepsilon V$ & 11 & $r \cdot$ & 0 & 11 & مركز الباسل لجر احة القلب \\
\hline rT. & $\varepsilon V$ & $1 \cdots$ & rT & $\Lambda V$ & المجموع \\
\hline
\end{tabular}

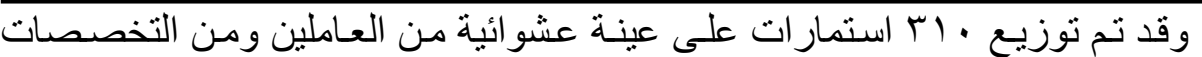

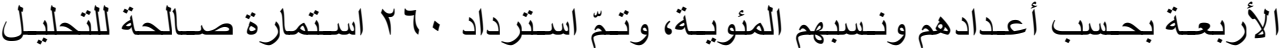

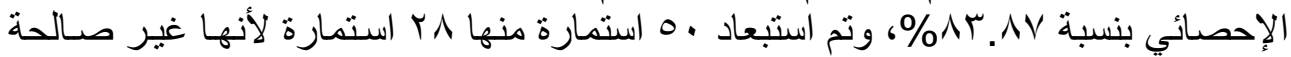

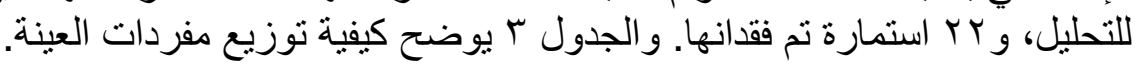

\section{حدود البحث}

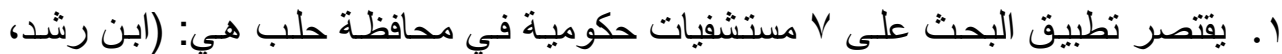

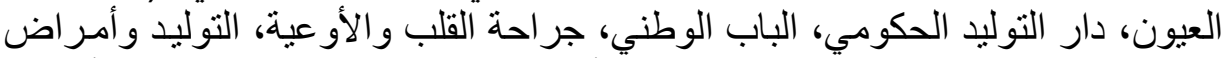

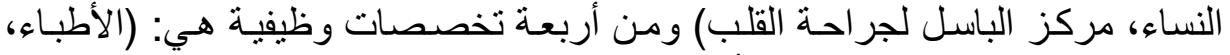

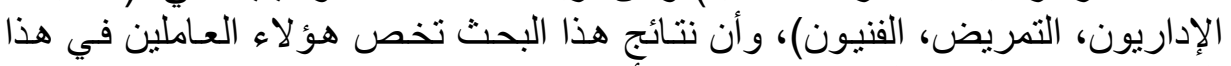

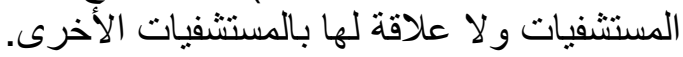

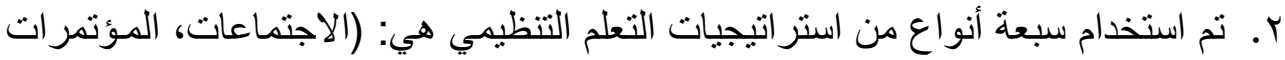

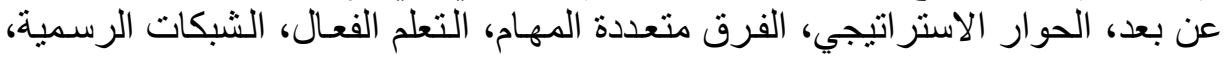

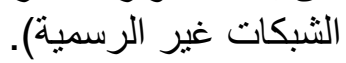

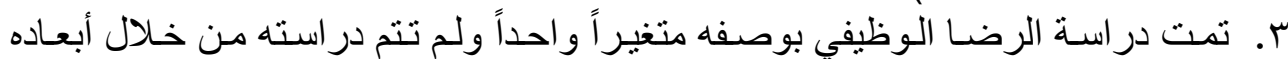

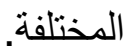
ـ. تم استخدام مستوى ثقة 90\% في اختبار صحة الفروض وتعميم النتائج.

الإطار النظري

المقدمة

حظيت ظاهرة التعلّم داخل المنظمات باهتمـام كبير في مجال العلوم الإنسانية بصفة

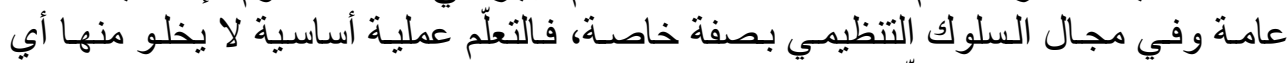

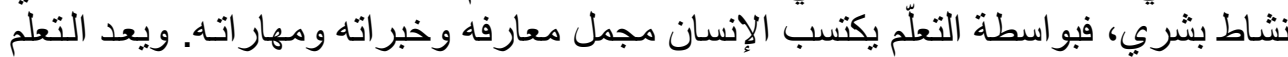

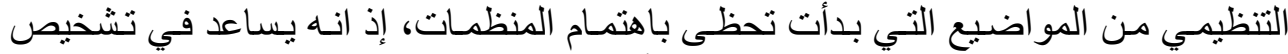

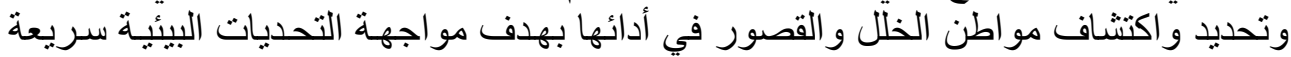




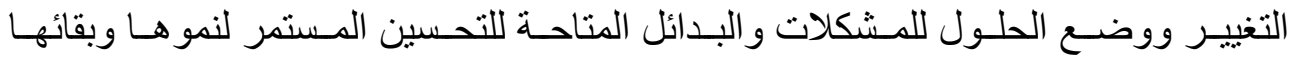

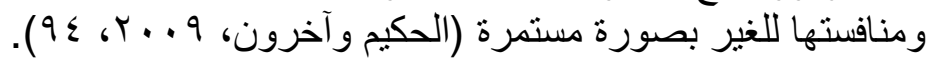

Organizational Learning التعلّم التنظيمي التمعار

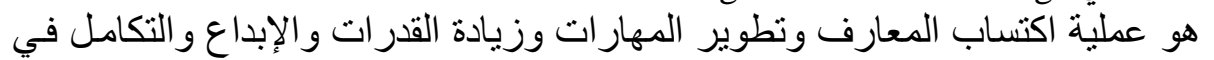

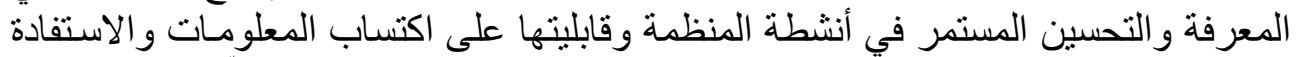

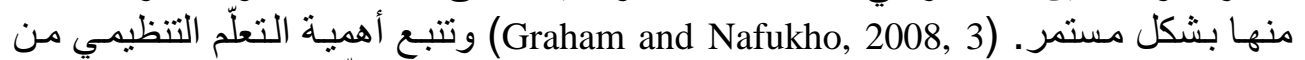

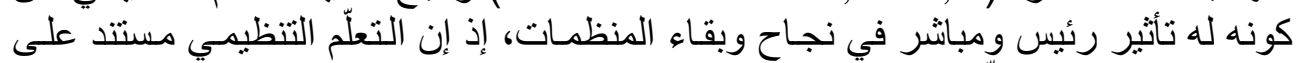

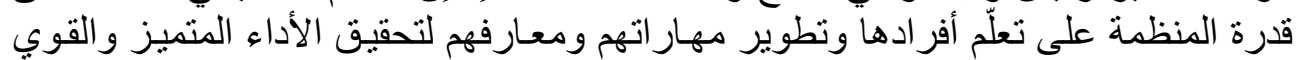
و القدرة على المنافسة (Arbel, 2009, 17).

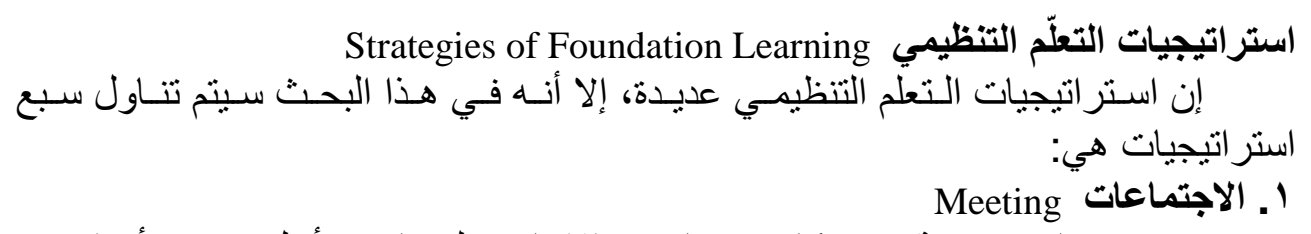

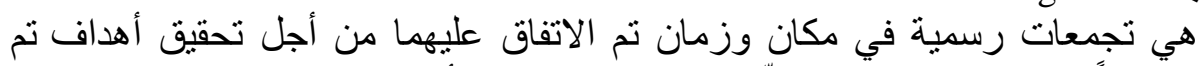

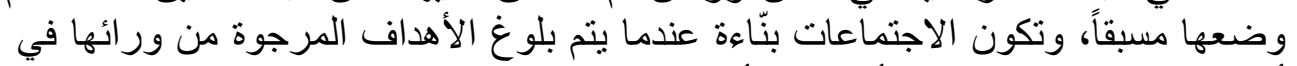

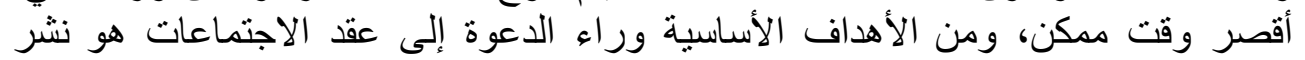

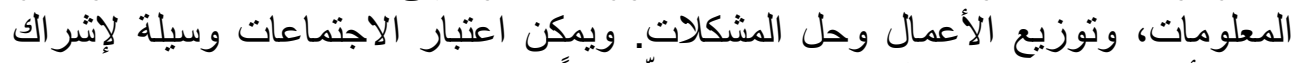

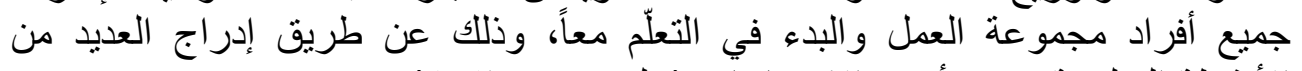

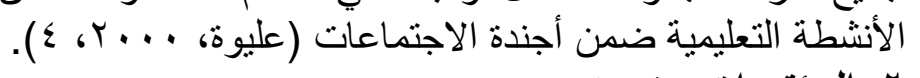

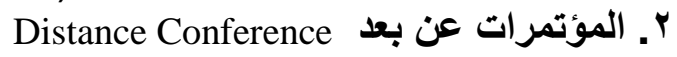

هي طريقة تقوم على عقد اجتماعات عن بعد باستخدام التقنيات المناسبة بهدف تبادل

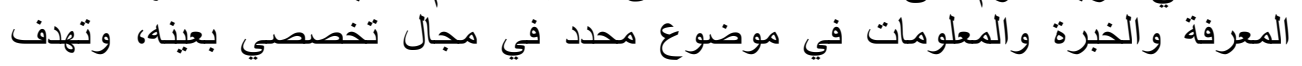

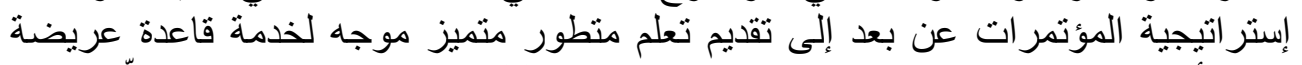

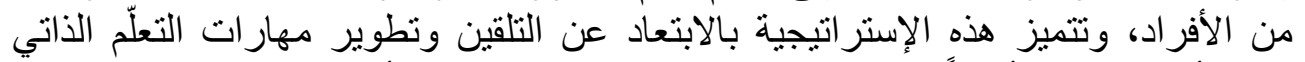

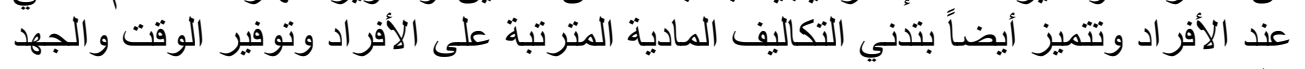

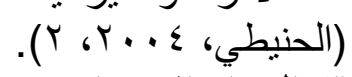

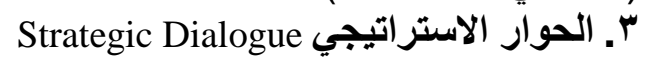

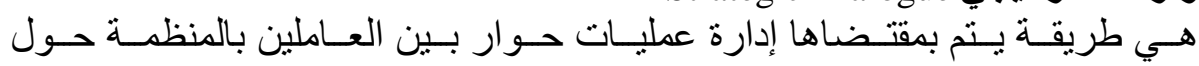

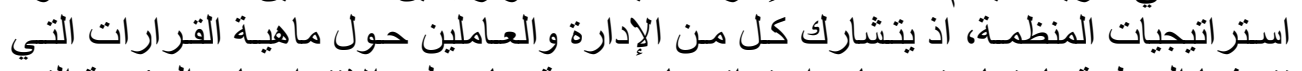

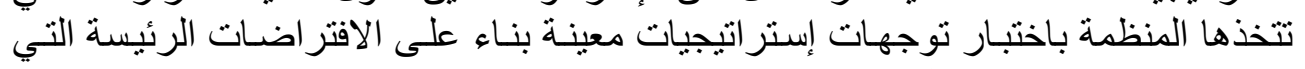

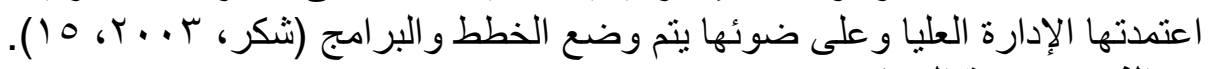

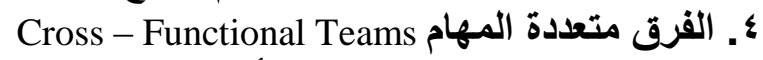

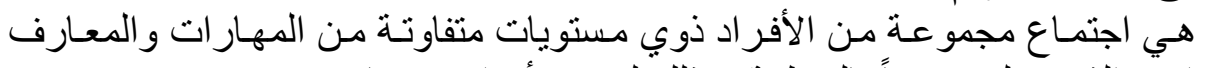

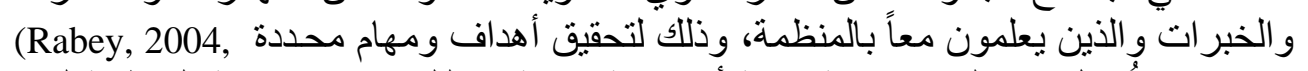

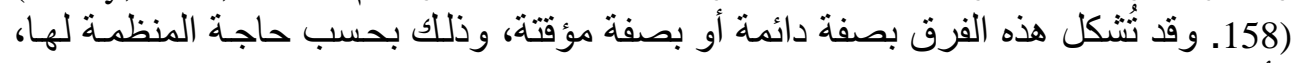

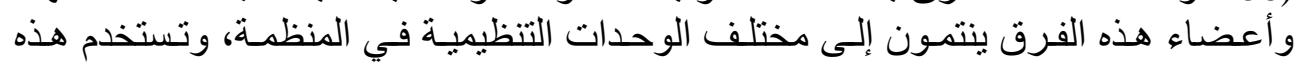




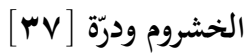

الفرق لتحقيق الانسيابية والمرونـة في عمل المنظمـات ولحل المشكلات ولتحقيق مهمـات تتطلب استخدام عميق للمعرفة و المهار ات و الخبرات (Waddell, Power, 2004, 7)

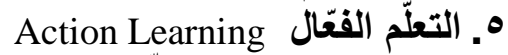

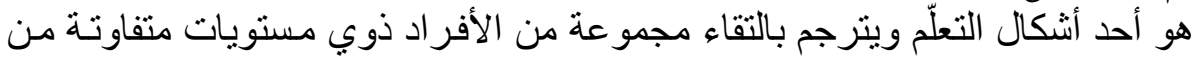

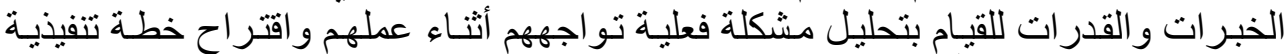

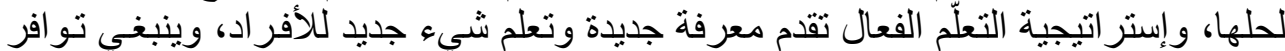

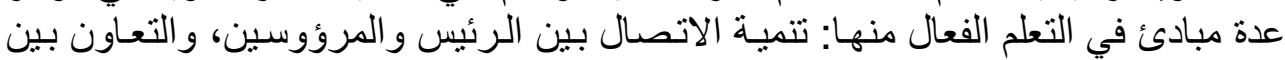

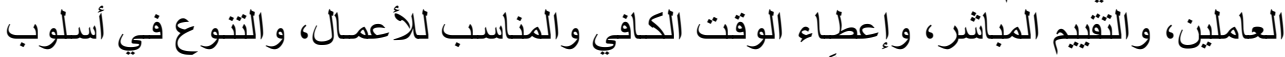
العرض وفي أسلوب التقييم أيضاً (Gamson and Checkering, 2008, 23)

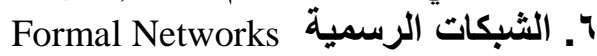

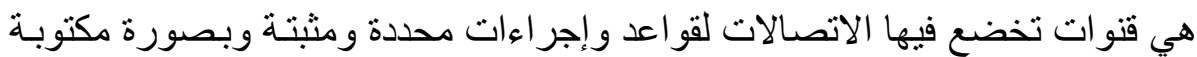

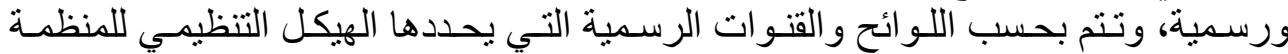

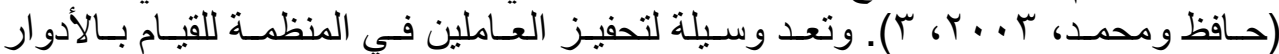

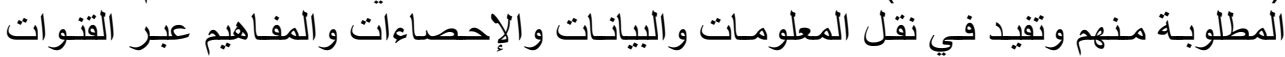

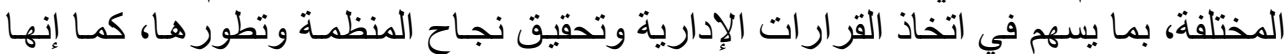

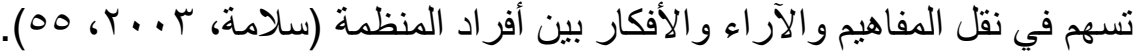

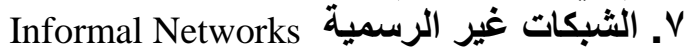

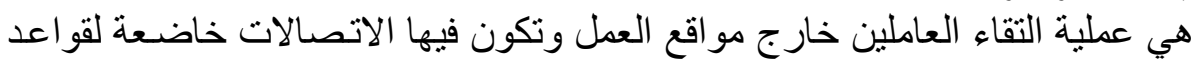

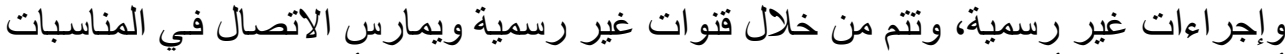

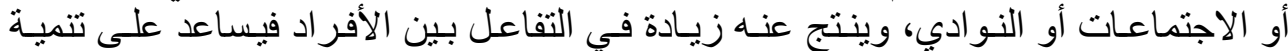

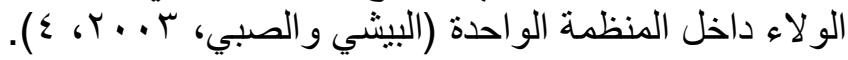

Job Satisfaction الرضا الوظيفي

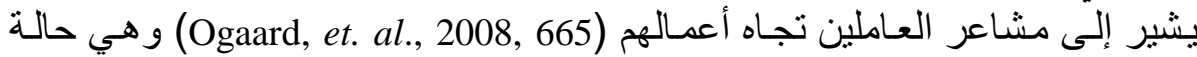

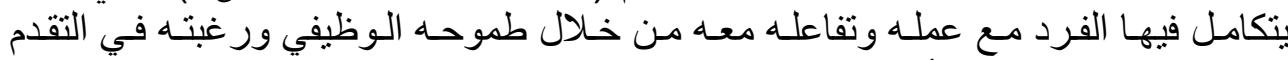

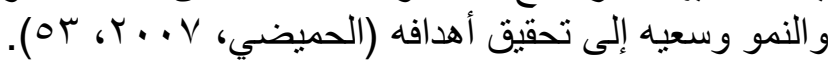

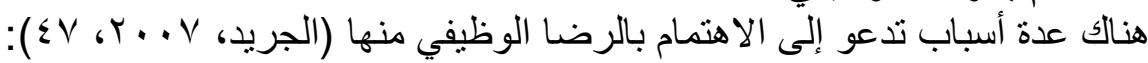
ا. إن ارتفاع درجة الرضا الوظيفي يؤدي إلى الرئى الخفاض نسبة غياب العاملين في منظماتهم. r. . إن ارتفاع مستوى الرضا الوظيفي يؤدي إلى ارتفاع مستوى الطموح لدى العاملين في

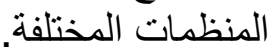
r. إن الأفراد الذين يتمتعون برضات وظيفي مرتفع يكونون أكثر رضاً عن وقت فر اغهم

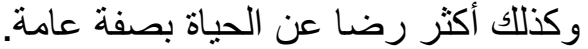

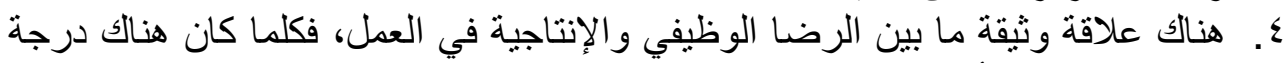
عالية من الرضا أدى إلى زئه ميادة الإنتاجية. 


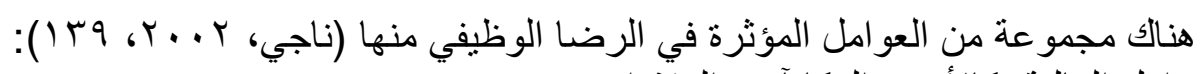

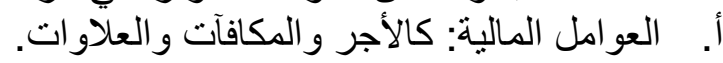

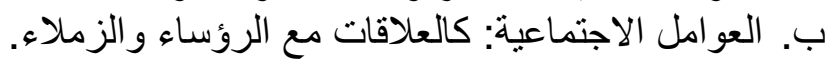

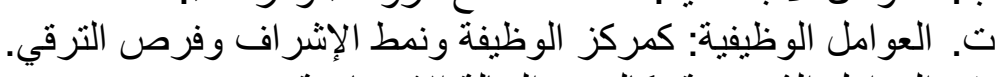
ث. ث. العوامل الثخصية: كالسن والحنالة الاجتماعية.

$$
\begin{aligned}
& \text { أبعاد الرضا الوظيفي التئية }
\end{aligned}
$$

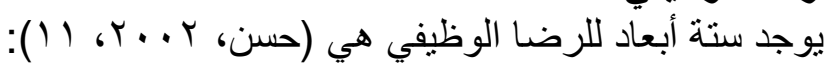

$$
\begin{aligned}
& \text { 1. الرضا عن العائد و المز اليا. } \\
& \text { r. الرضا عن العلاقة مع الزملاء. الرضاء }
\end{aligned}
$$

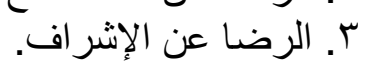

$$
\begin{aligned}
& \text { ع. الرضا عن محتوى العمل. } \\
& \text { ه. } \\
& \text { 1. الرضا العام عن الوظيفة. }
\end{aligned}
$$

الاراسات العابقة

$$
\text { أولاً الاراسات العابقة العربية }
$$

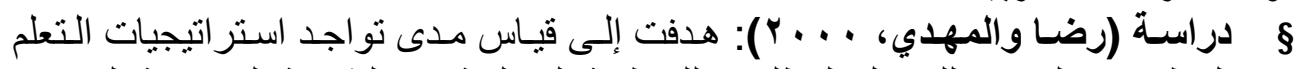

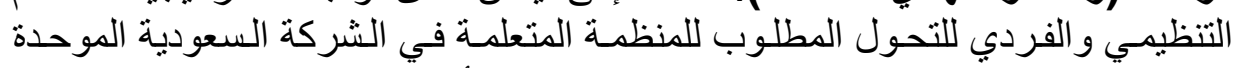

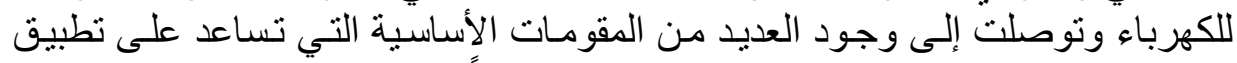

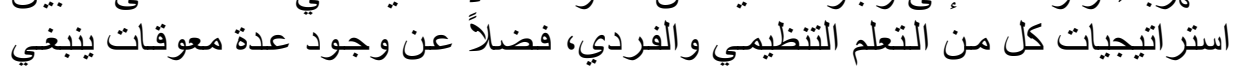

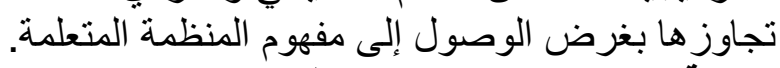

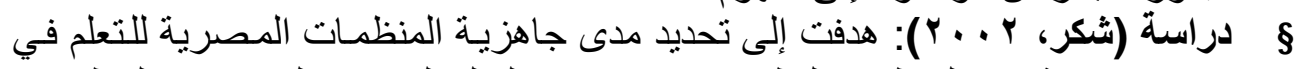

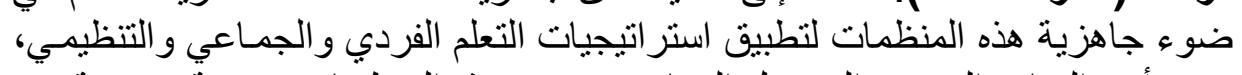

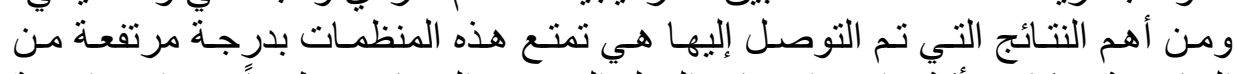

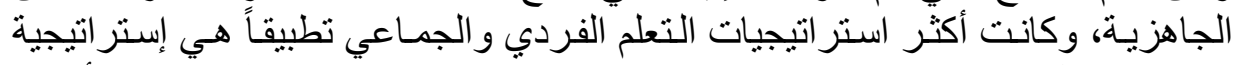

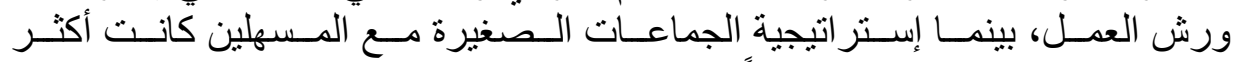
استر اتيجيات التعلم التنظيمي تطبيقاً.

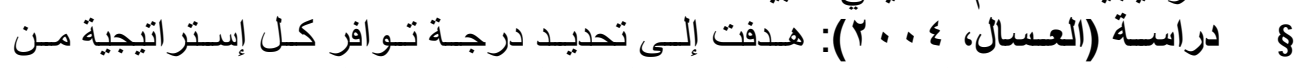

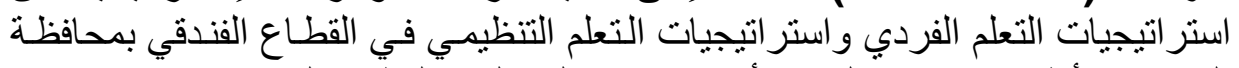

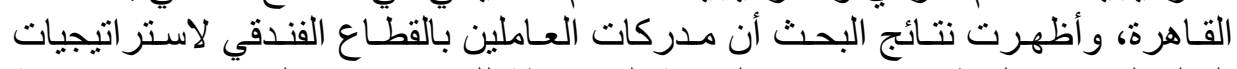

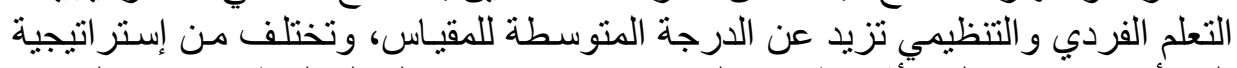

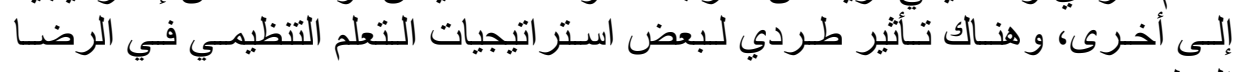

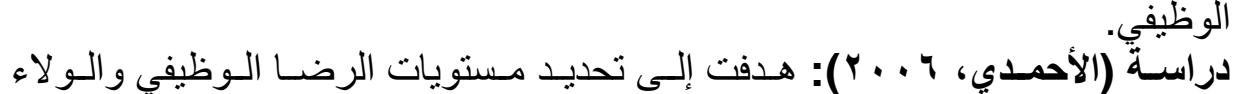

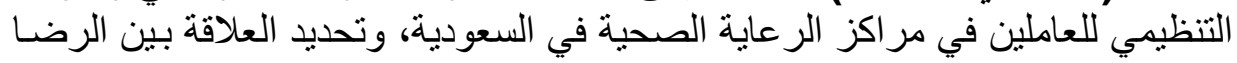

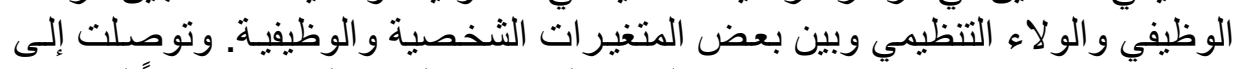

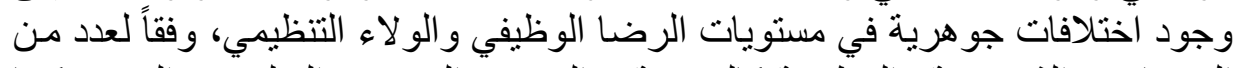

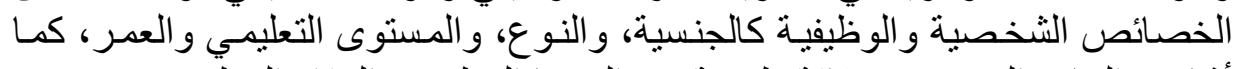

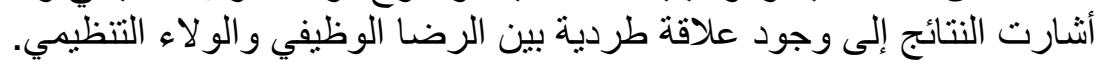




\section{[ الخشروم ودرّة [جa}

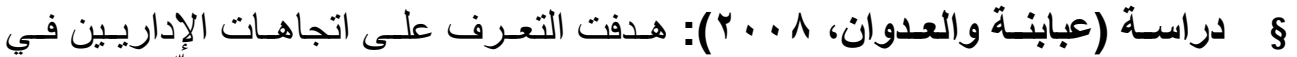

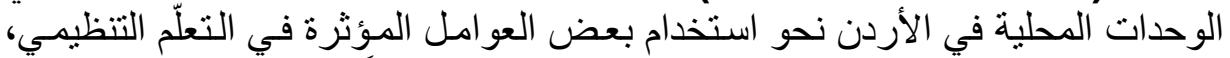

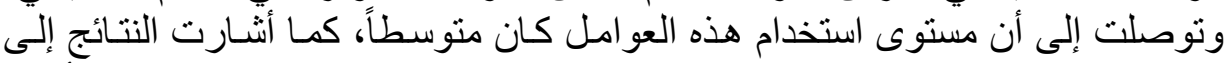

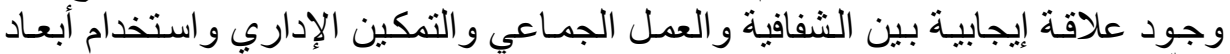
التعلّم التنظيمي.

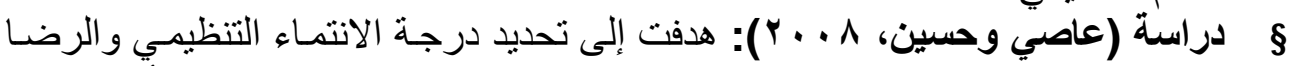

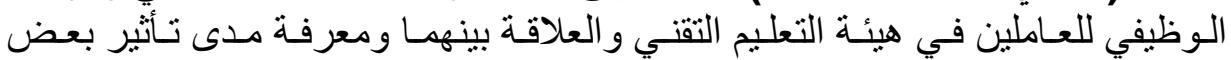

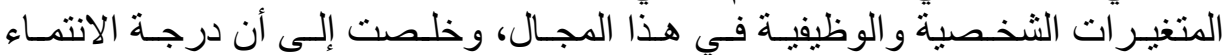

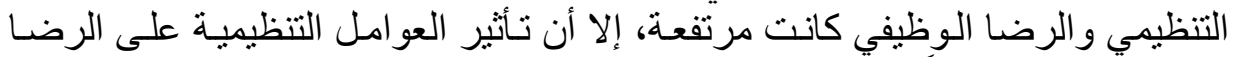

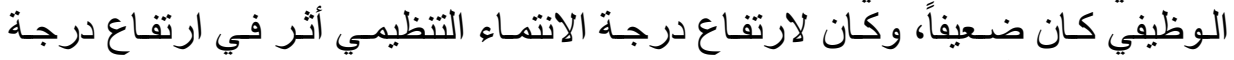

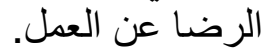

\section{ثانياً الار اسات الأجنبية}

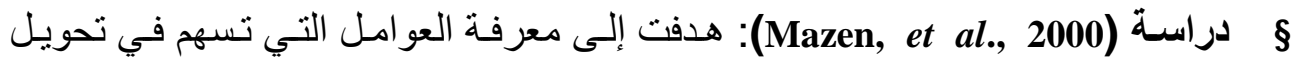

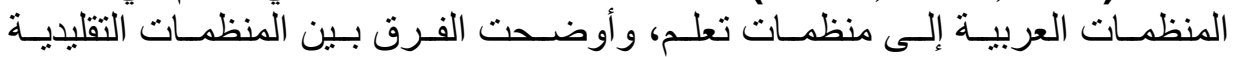

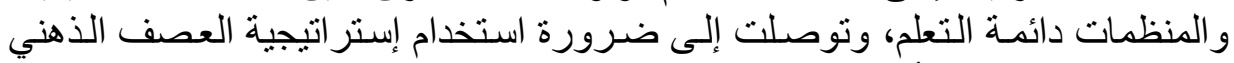
في التعلم و التدريب للأفر اد و المديرين كإحدى استر اتيجيات التعلم التنظيمي وذللك لمـا. لهذه الإستر اتيجية من أهمية في علاج الكثير من المشكلات التنظيمية.

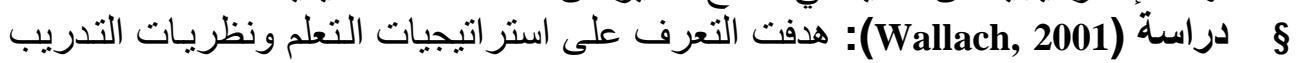

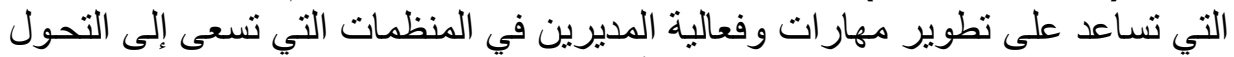

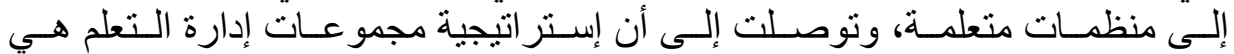

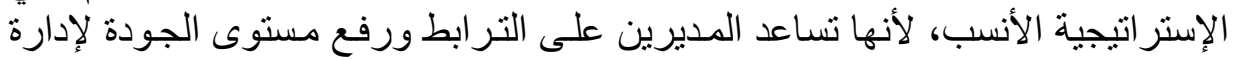

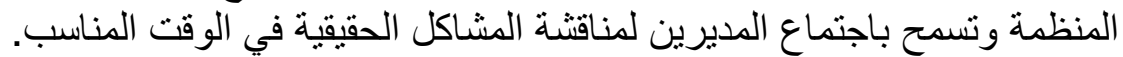

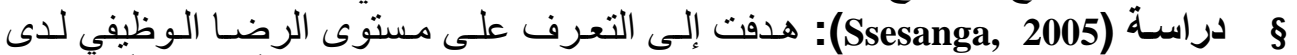

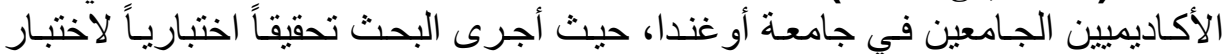

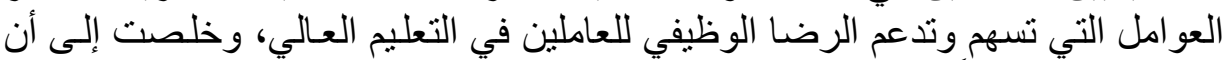

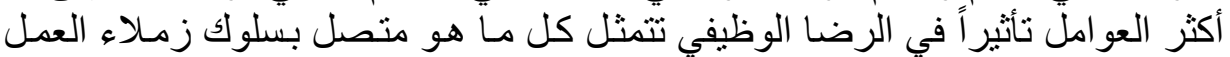

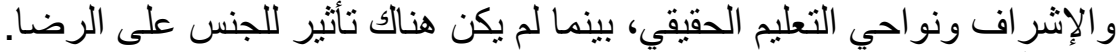

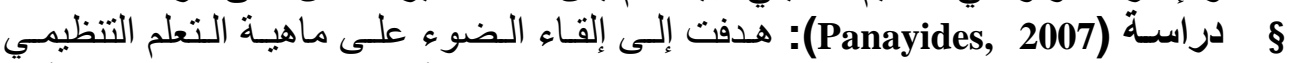
و القيود التي تعيق تطبيقه في المنظمات الخدمية، وتحديد أثر التعلم التنظيمي على التى الأداء

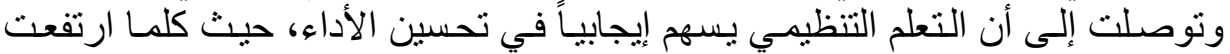
مستويات التعلم التنظيمي ارتفعت مستويات الأداء بين العاملين في الثركات.

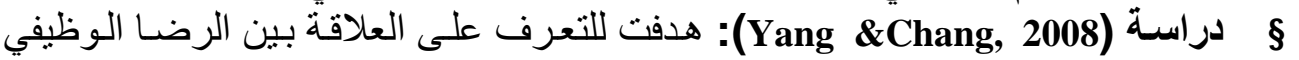

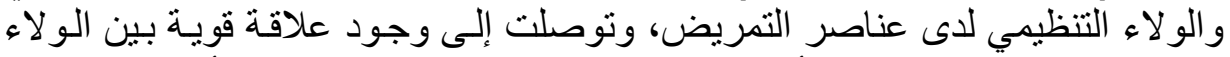

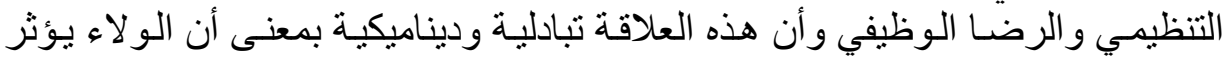

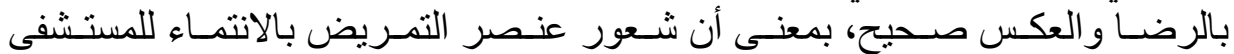

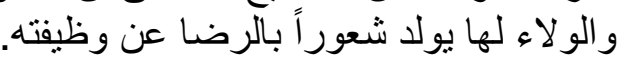

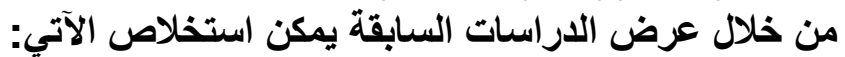

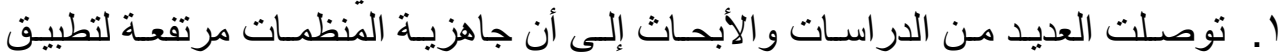
استر اتيجيات التعلم التنظيمي وتختلف من إستر اتيجية إلى أخرى. 


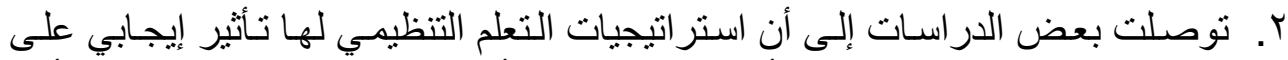

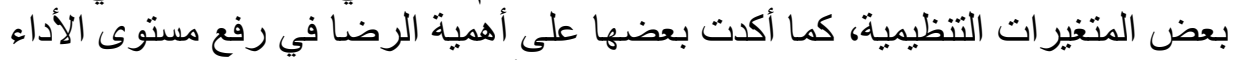

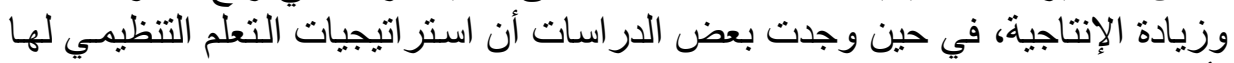
تأثير طردي على الإنتاجئ في الرضا. r. يختلف هذا البحث عن الدراسات السابقة في تحديد الأهمية النسبية لكل إستر اتيجية من

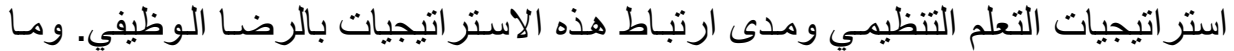

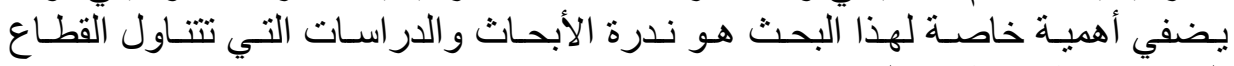
الصحي كقطاع تطبيقي لها.

تحليل البيانات واختبار الفرضيات أولاةً - وصف خصائص العينة

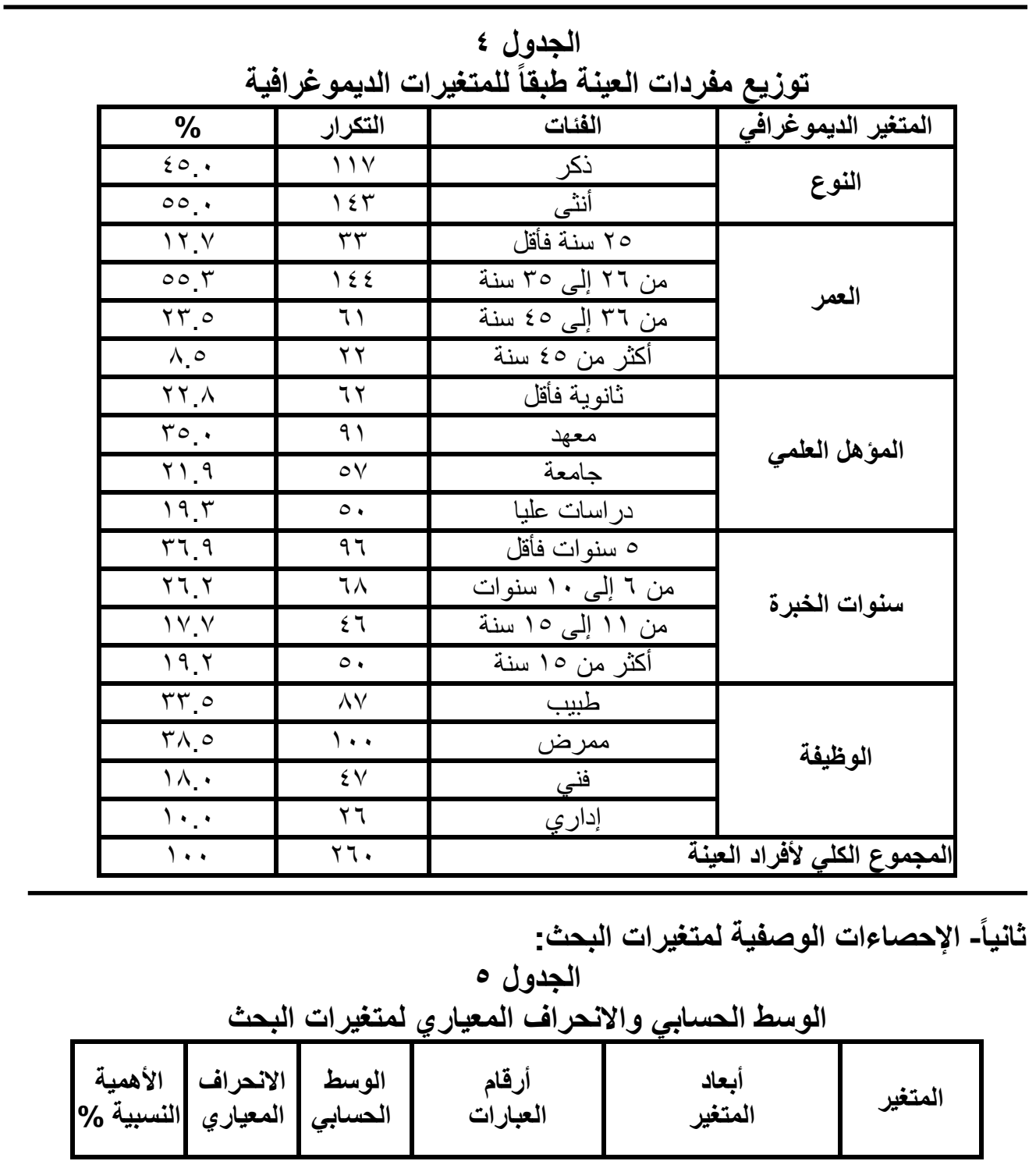




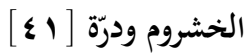

\begin{tabular}{|c|c|c|c|c|c|}
\hline$T V . Y$ & $\cdot .9 \cdot \varepsilon$ & ד. & (من ا إلى ץ) & الاجنماعات & \multirow{7}{*}{ التنتراتيجيات } \\
\hline 07.7 & 1.1 & $r . r \Lambda$ & (من ؟ إلى 7) & المؤتمر ات عن بعد & \\
\hline Tr. & .994 & 5.10 & (من V إلى 9) & الحوار الاستر اتيجي & \\
\hline $7 V . \Lambda$ & $\cdot \wedge \cdot \wedge$ & $r . r q$ & (من · ( إلى Y I) & الفرق متعددة المهام & \\
\hline $7 V_{.}$. & $\cdot .9 \leqslant 7$ & r.ro & (من س 1 إلى 0 () & التعلم الفعال & \\
\hline $7 Y .7$ & $1 . .1$ & 5.14 & (من 17 إلى (1) & الثبكات الرسمية & \\
\hline 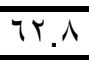 & $\therefore \wedge 1 \wedge$ & r.1 & (من 19 إلى (Y) & الثبكات غير الرسمية & \\
\hline ג & $\therefore \vee 01$ & $r .19$ & (من ا إلى اYr) & ستراتيجيات & التقلم المق \\
\hline$T \leq . Y$ &.$V Y V$ & $r . r$ & (من זr إلى هץ) & & \\
\hline
\end{tabular}

يتبيّن من الجدول ه ما يأتي:

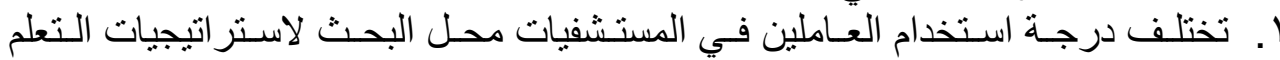

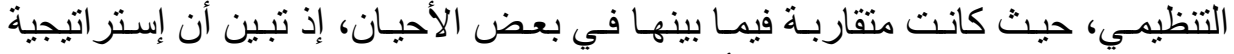

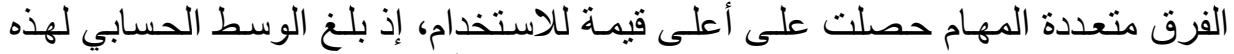

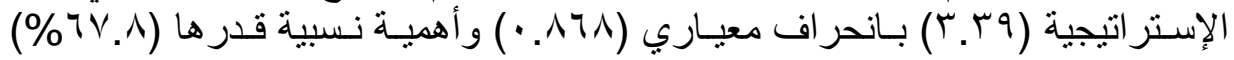

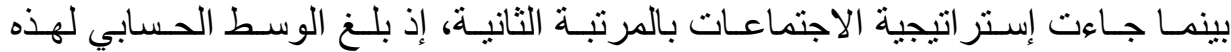

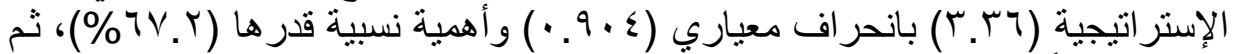

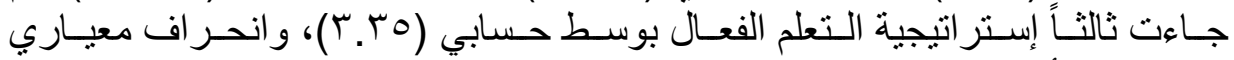

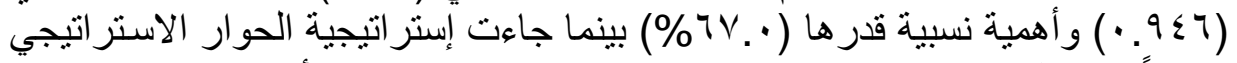

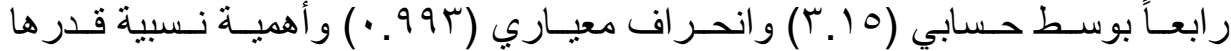

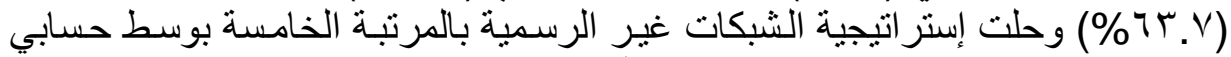

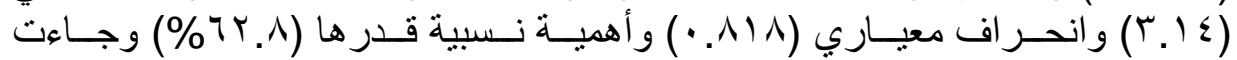

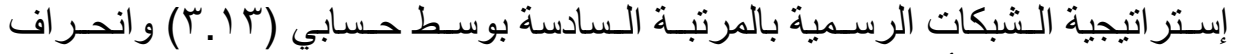

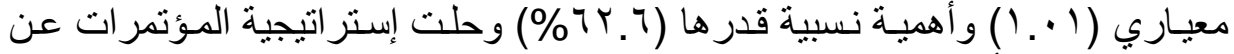

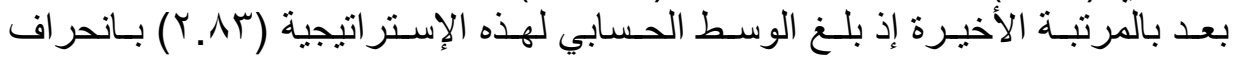

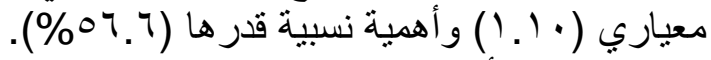

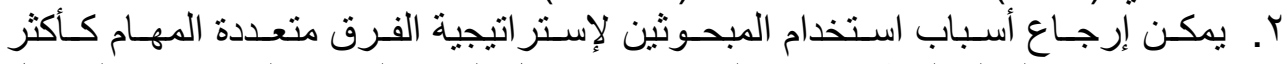

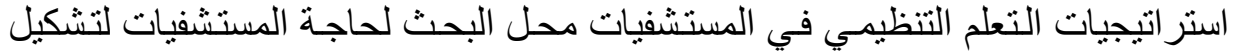

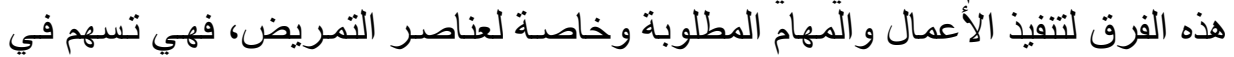

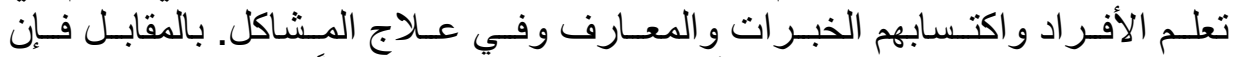

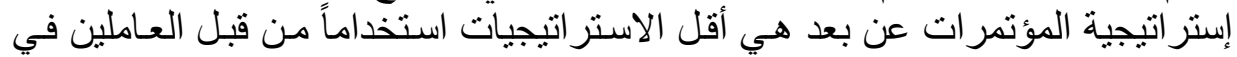

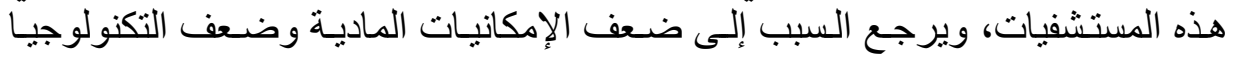

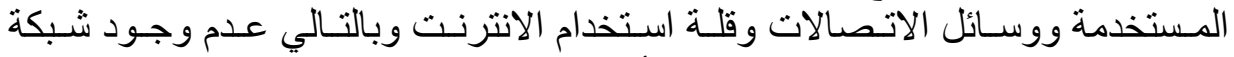

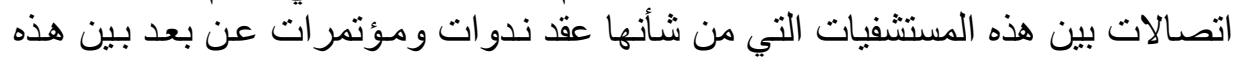

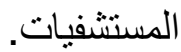

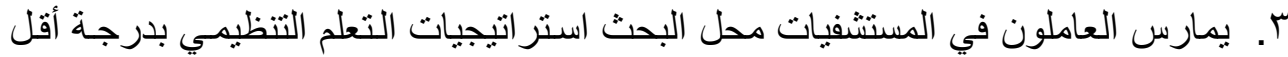
من المنوسطة (•ع.ب)، حيث بلغ الوسط الحسابي للمقياس الكلي لاستر اتيجيات التعلم 


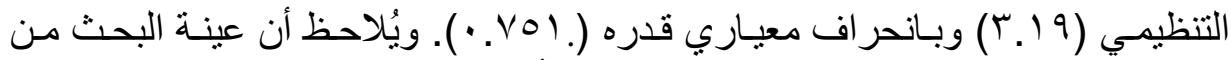

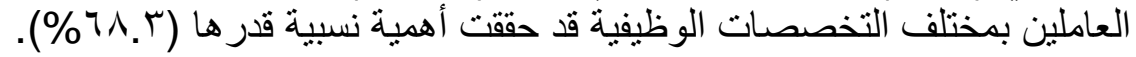

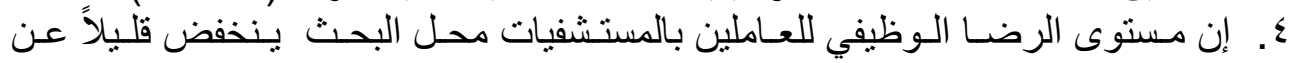

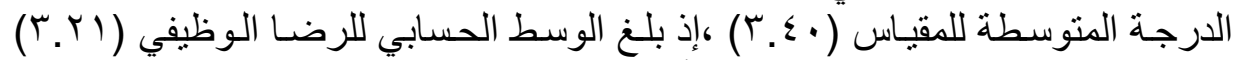

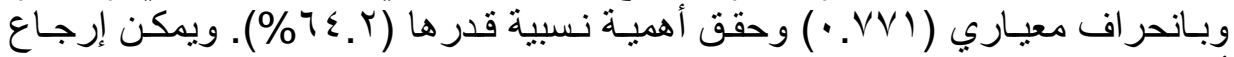

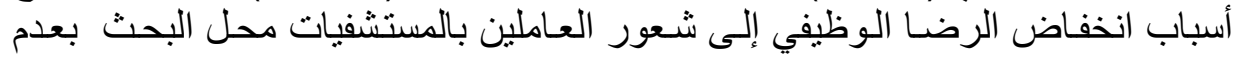

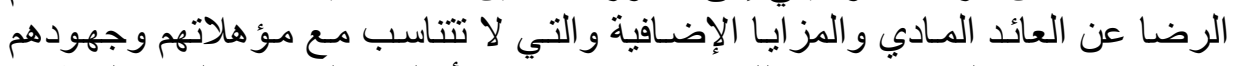

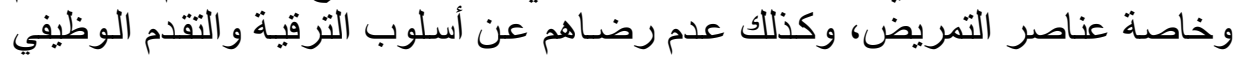

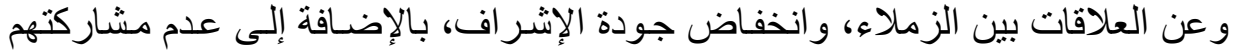
في اتخاذ القرار ات المتعلقة بوظائفهم.

ثالثاً اختبار الفرضيات

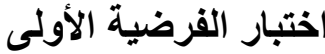

لا توجد اختلافات جو هرية ذات دلاتلة دالة إحصائية بين فئات العاملين (أطباء، تمريض،

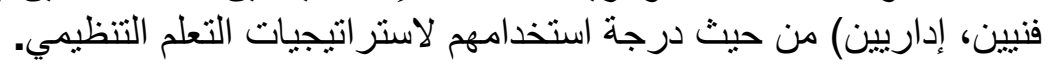

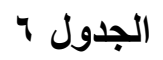

الوسط الحسابي والانحراف المعياري لاستراتيجيات التعلم التظيمي بحسب الوظيفة

\begin{tabular}{|c|c|c|c|c|c|}
\hline الإجمالي & الإداريين & الفنيين & التمريض & الأطباء & البيان \\
\hline Y.. & YT & $\sum V$ & $1 \ldots$ & $\Lambda V$ & التكر ار \\
\hline 5.19 & $r . r q$ & $r . \leqslant 0$ & $r . \cdot v$ & $r .1 T$ & الوسط الحسابي \\
\hline$\therefore \times 01$ & .911 & $\therefore \varepsilon \vee q$ & $\cdot .10 \leqslant$ & $.70 Y$ & الانحر اف المعياري \\
\hline
\end{tabular}

يُلاحظ من الجدول 7 أن درجة استخدام العاملين لاستر اتيجيات التعلم التنظيمي كانت

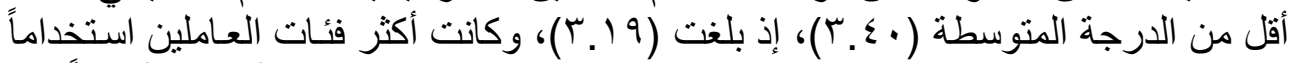

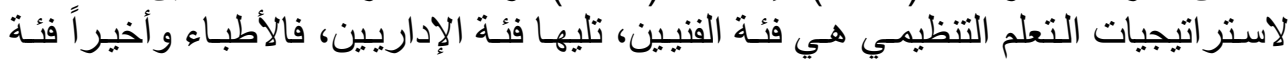

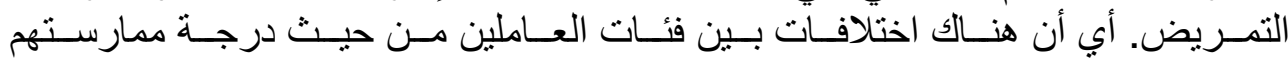

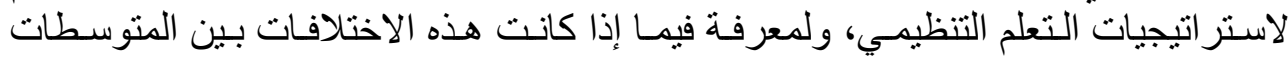

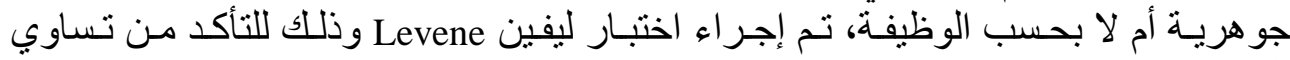

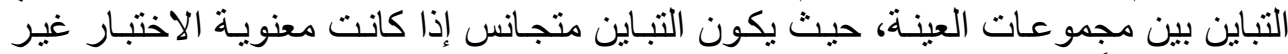

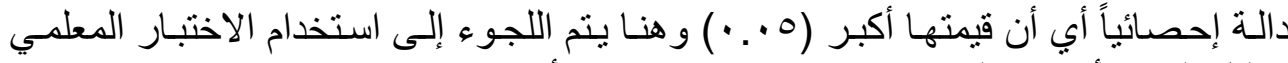

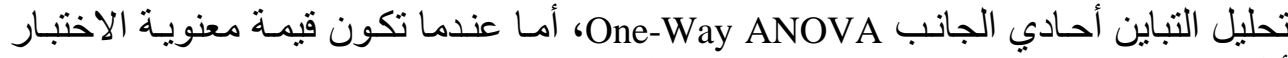

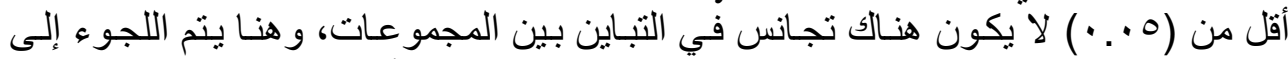

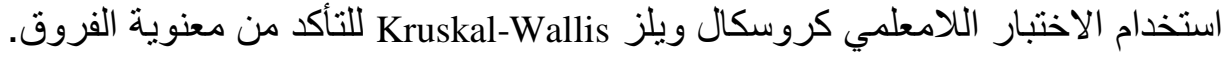

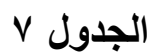

اختبار Levene لاستر اتيجيات التعلم التظيمي حسب الوظيفة

\begin{tabular}{|c|c|c|}
\hline المعنوية & درجات الحرية & قيمة ليفين \\
\hline$\because$ & r07 & $v_{\text {. }} \varepsilon$ \\
\hline
\end{tabular}




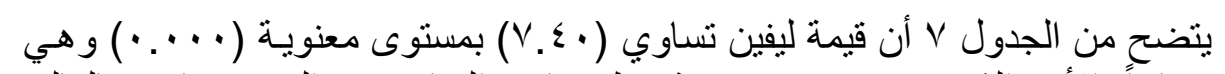

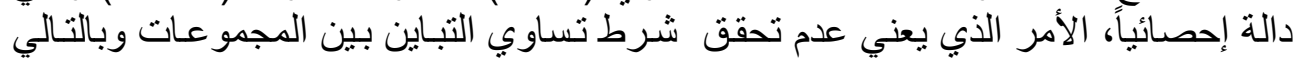

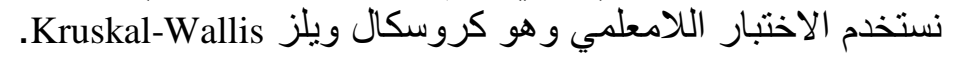

\begin{tabular}{|c|c|c|c|c|c|c|}
\hline \multicolumn{7}{|c|}{ نتائج اختبار كروسكال ويلز لتأثير الوظيفة في استراتيجيات التعلم التنظيمي } \\
\hline الإحصائية & المعنوية & كاي تربيع & ح.د & متوسط الرتب & الوظيفة & \\
\hline \multirow{4}{*}{ معنوية } & \multirow{4}{*}{$\because \cdots 9$} & \multirow{4}{*}{$11 . \leq 9$} & \multirow{4}{*}{$r$} & 151.19 & طبيب & \multirow{4}{*}{ 可方 } \\
\hline & & & & $T Y \cdot Y \varepsilon$ & ممرض & \\
\hline & & & & $10 \% .11$ & فني & \\
\hline & & & & 101.74 & إداري & \\
\hline
\end{tabular}

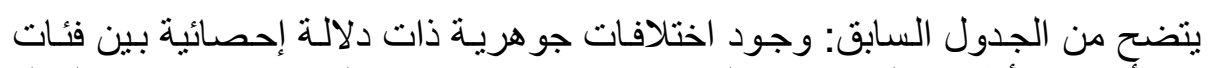

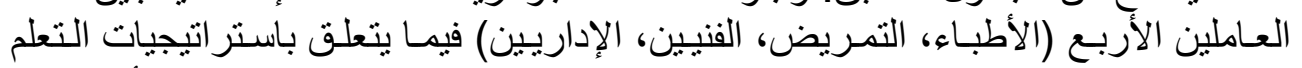

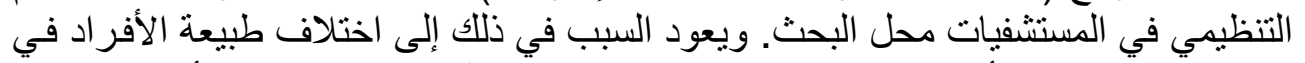

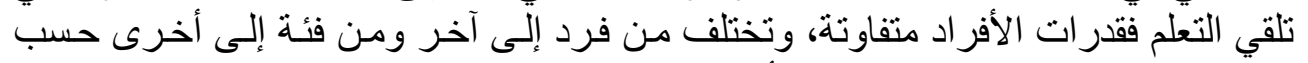

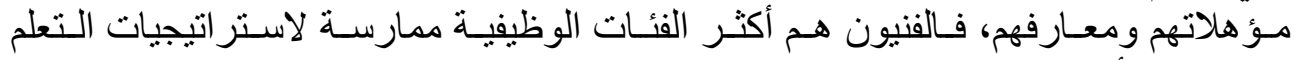

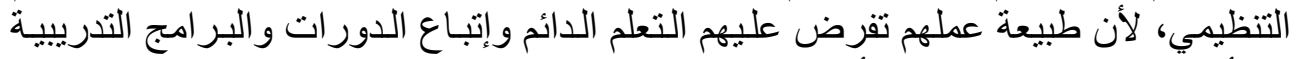

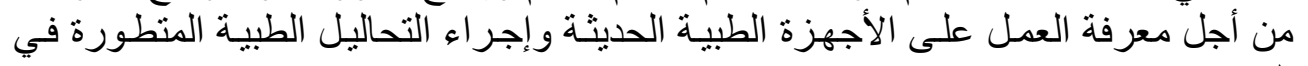

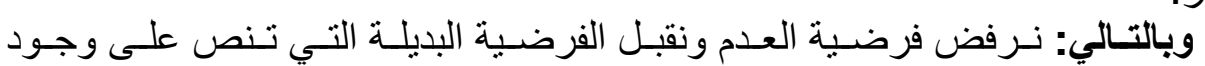

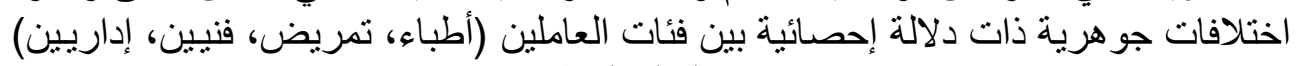
من حيث درجة استخدامهم لاستر اتيجيات التعلم التنظيمي. اختبار الفرضية الثانية لا توجد اختلافات جوهرية ذانية ذات دلالة إحصائية بين فئات العاملين (أطباء، تمريض،

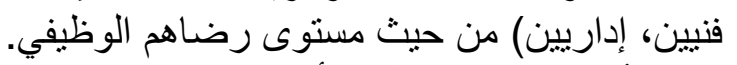

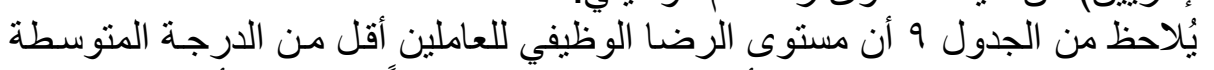

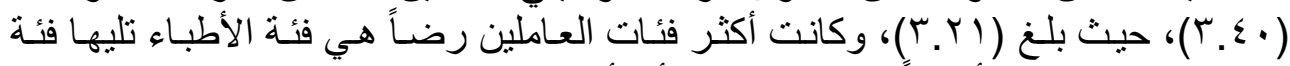

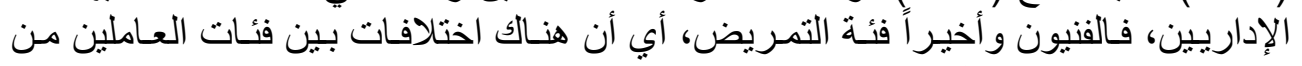
حيث مستوى رضاهم الوظيفي.

\section{الجدول 9}

الوسط الحسابي والانحراف المعياري للرضا الوظيفي بحسب الوظيفة

\begin{tabular}{|c|c|c|c|c|c|}
\hline الإجمالي & الإداريين & الفنيين & التمريض & الأطباء & البيان \\
\hline r. & rT & $\sum V$ & $1 \ldots$ & $\Lambda V$ & التكر ار \\
\hline T.Y & T.YA & r.IT & 5.11 & r.ro & الوسط الحسابي \\
\hline..$V \vee 1$ & .790 &.$\vee \wedge 0$ & $\therefore \wedge Y_{0}$ & $.8 \cdot 9$ & الانحر اف المعياري \\
\hline
\end{tabular}




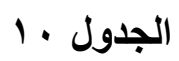

اختبار Levene للرضا الوظيفي حسب الوظيفة

\begin{tabular}{|c|c|c|}
\hline المعنوية & درجات الحرية & قيمة ليفين \\
\hline $.1 \wedge \mathrm{V}$ & roT & 1.71 \\
\hline
\end{tabular}

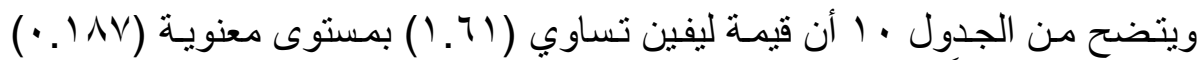

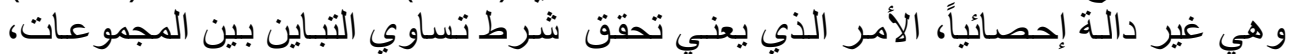

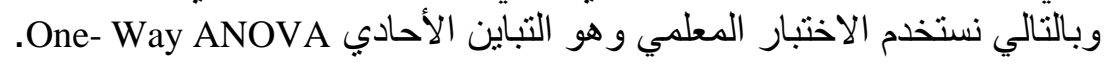

\begin{tabular}{|c|c|c|c|c|c|c|c|}
\hline \multicolumn{8}{|c|}{ تحليل التباين الأحادي للرضا الوظيفي حسب الوظيفة 1 الجديف } \\
\hline الإحصائية & المعنوية & $\begin{array}{c}\text { قيمة } \\
\text { F }\end{array}$ & المتوسط & الحرجات & المجبعات & مصدر & المتغير \\
\hline \multirow{3}{*}{ جوهرية } & \multirow[t]{3}{*}{$.1 \leq V$} & \multirow[t]{3}{*}{$1 . \wedge$} & 1.97 & $r$ & 5.11 & بين الفئات & \multirow{3}{*}{ الوظيفي } \\
\hline & & & .0199 & Y07 & $10 . .11$ & داخل الفئات & \\
\hline & & & & roq & 104.99 & التباين الكلي & \\
\hline
\end{tabular}

يتضح من الجدول / 1 عدم وجود اختلافات جوهريـة ذات دلالة إحصائية بين فئسات

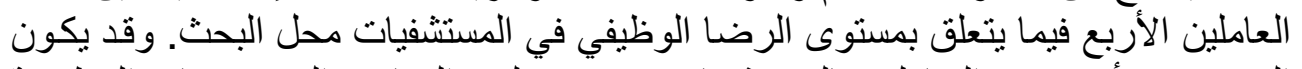

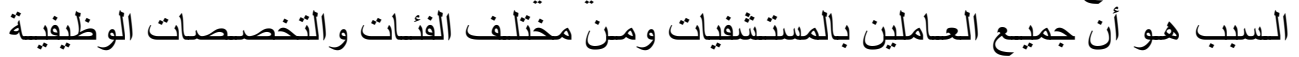

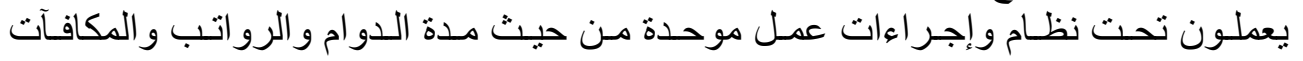

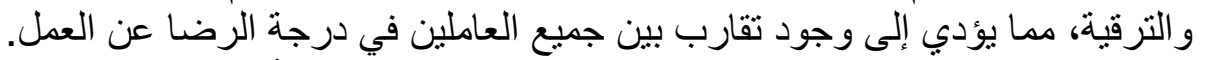

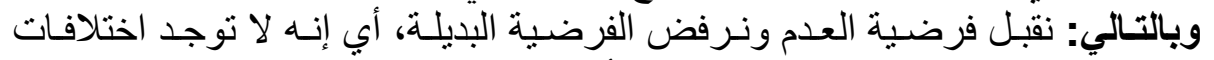

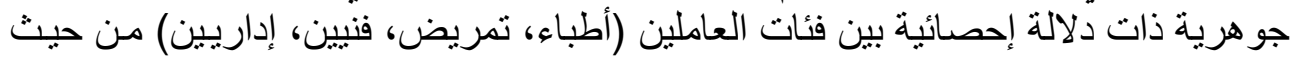
مستوى رضاهم الوظيفي.

اختبار الفرضية الثالثة

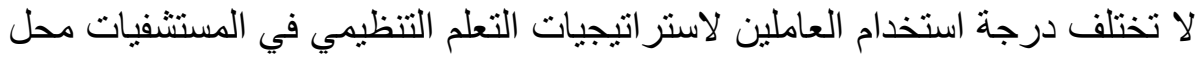

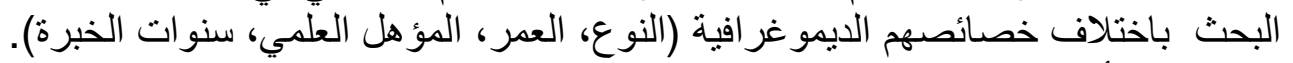

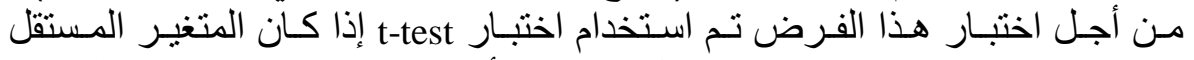

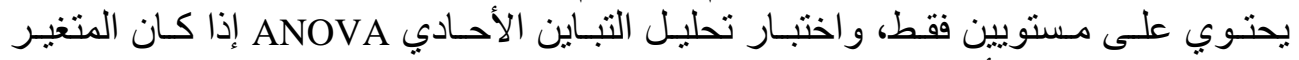
المستقل يحتوي على أكثر من مستوبين.

\begin{tabular}{|c|c|c|c|c|c|c|c|}
\hline \multicolumn{8}{|c|}{ 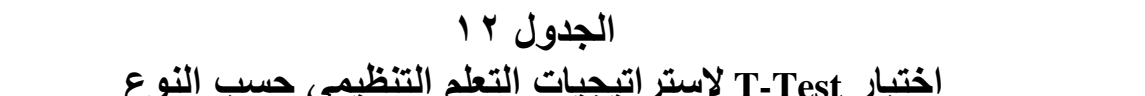 } \\
\hline الإحصائية & المعنوية & قيمة T & ال الانحراف & | الوسط & التكرار & النوع & المتغير \\
\hline
\end{tabular}


الخشروم ودرّة [0 [ع]

\begin{tabular}{|c|c|c|c|c|c|c|c|}
\hline \multirow{2}{*}{ جوهرية } & \multirow[t]{2}{*}{$\because .97$} & \multirow[t]{2}{*}{$1.7 \mathrm{~V}$} & $\cdot 7 \lambda \varepsilon$ & T.YA & $11 \mathrm{~V}$ & ذكر & \multirow{2}{*}{ استراتيجيات التنظيمي } \\
\hline & & & $\because \vee \vee ৭ \wedge$ & $r . \mid r$ & $1 \leqslant r$ & أنثى & \\
\hline
\end{tabular}

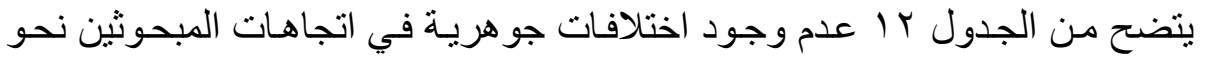

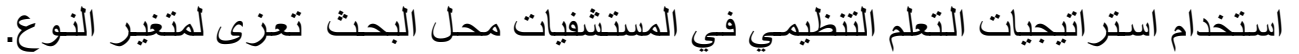

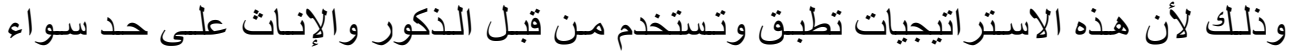

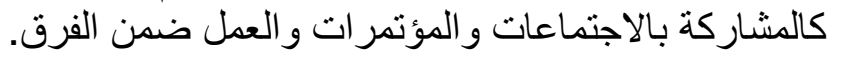

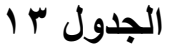

تحليل ANOVA لاستر اتيجيات التعلم وفقاً للمتغير ات الايموغر افية

\begin{tabular}{|c|c|c|c|c|c|c|c|}
\hline الإحصائية & المعنوية & قيمة F & المتوسط & الحرجيةت & المربعوت & التباين & الديموغرافي \\
\hline \multirow{3}{*}{ جوهرية غير } & \multirow[t]{3}{*}{.9 .7} & \multirow[t]{3}{*}{.710} & $\cdot r \leqslant q$ & $r$ & $1 . \leqslant \Lambda$ & بين الفئات & \multirow{3}{*}{ العمر } \\
\hline & & & $.07 \mathrm{~V}$ & Y07 & $1 \leq 0.11 \varepsilon$ & داخل الفئات & \\
\hline & & & & roq & IST.YT. & التباين الكلي & \\
\hline \multirow{3}{*}{ جو هرية } & \multirow[t]{3}{*}{$\because .17$} & \multirow[t]{3}{*}{ r.0.乏 } & $1.9 r T$ & $r$ & 0.1711 & بين الفئات & \multirow{3}{*}{ العؤهل } \\
\hline & & & $.0 \leq 9$ & ro7 & $1 \leqslant \cdot . \Sigma T Y$ & داخل الفئات & \\
\hline & & & & roq & IకT.YT. & التباين الكلي & \\
\hline \multirow{3}{*}{ جوهرية غير } & \multirow[t]{3}{*}{$\cdot r l \cdot$} & \multirow[t]{3}{*}{1.011} &.$\wedge 0 Y$ & $r$ & T.000 & بين الفئات & \multirow{3}{*}{ سنوات } \\
\hline & & & .071 & rot & $1 \leqslant r .7 \vee 0$ & داخل الفئات & \\
\hline & & & & roq & IET.YT. & التباين الكلي & \\
\hline
\end{tabular}

$$
\text { يتضح من الجدول با ا ما يأتي: }
$$

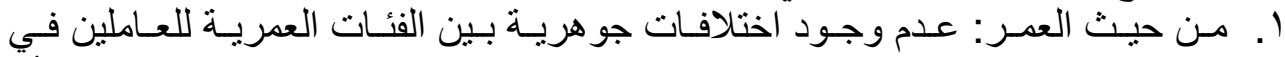

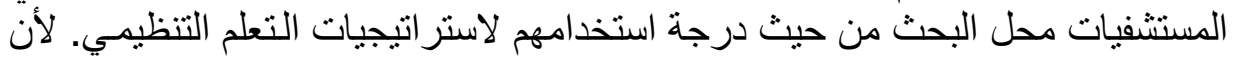

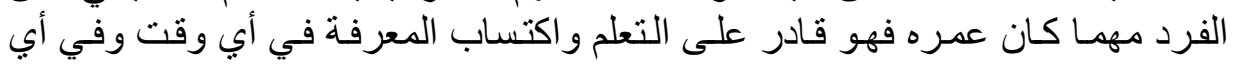

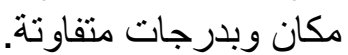

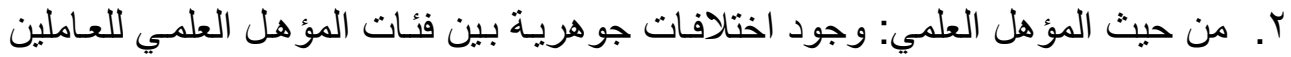

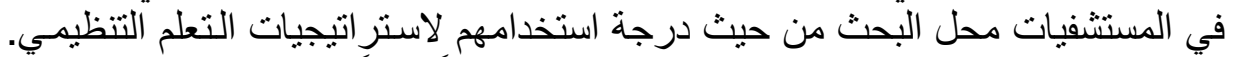

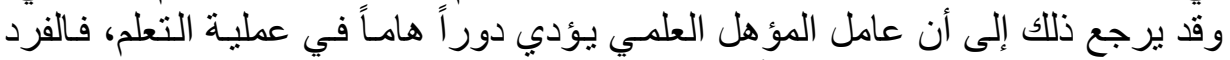

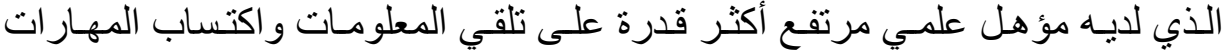

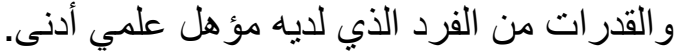

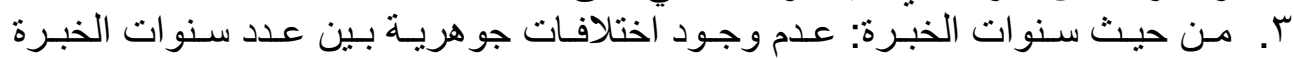

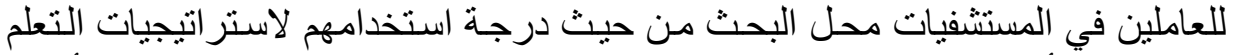

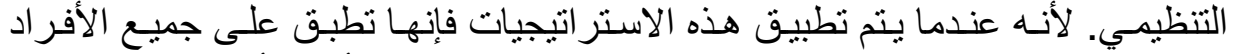

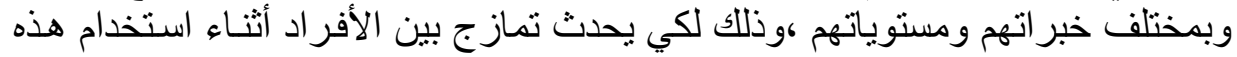

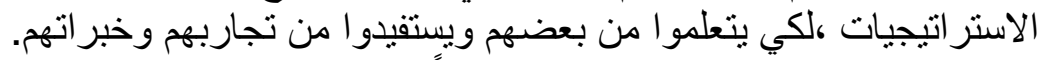

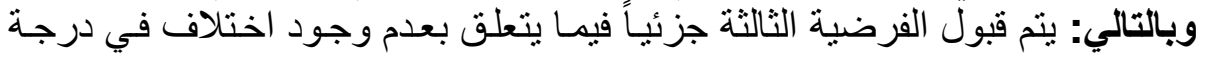

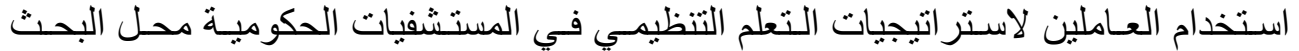


تُعزى لمتغير ات: (النوع، العمر، سنوات الخبرة). ويتم رفض الفرضية الثالثة جزئيساً فيما

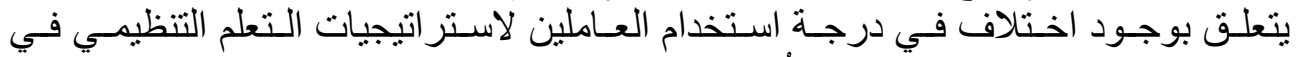

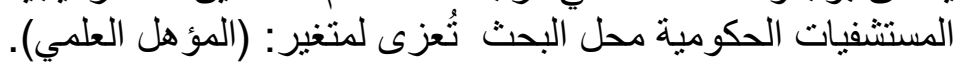

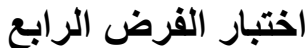

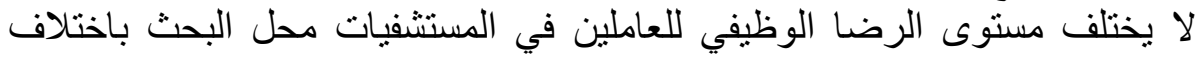
خصائصهم الديمو غر افية (النوع، العمر ، المؤهل العلمي، الخبرة).

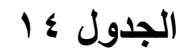

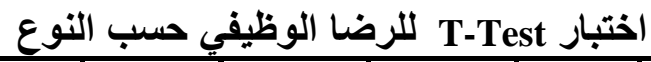

\begin{tabular}{|c|c|c|c|c|c|c|c|}
\hline الإحصائية & المعنو & قيمة T & الالانحراف & الألوبطي & التكرار & النوع & المتغير \\
\hline \multirow[t]{2}{*}{ و هرية } & \multirow[t]{2}{*}{$\because \varepsilon r$} & \multirow[t]{2}{*}{$r_{.} .0$} & 1. & $\overline{r . r T}$ & $11 \mathrm{~V}$ & ذكر & \\
\hline & & & $\lambda \cdot 4$ & r.M & $1 \leqslant r$ & & \\
\hline
\end{tabular}

يتضح من الجدول ؛ ا: وجود اختلافات جوهرية في اتجاهات المبحوثين نحو الرضا

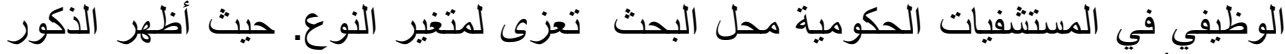

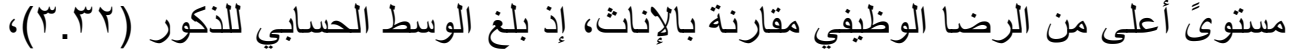

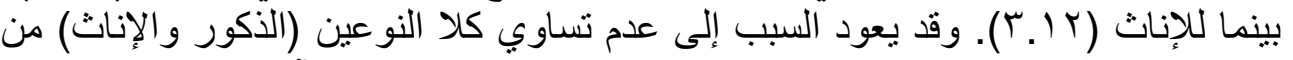

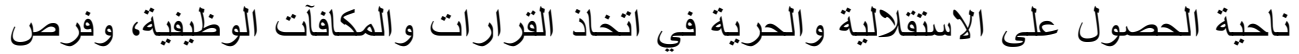

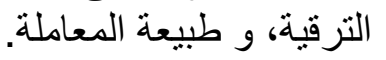

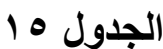

تحليل ANOVA للرضا الوظيفي وفقاً للمتغيرات الايموغر افية

\begin{tabular}{|c|c|c|c|c|c|c|c|}
\hline الإحصائية & المعنوية & قيمة F & المتوسط & الدرجية & المجبعوع & التباين & الايموغرافي \\
\hline \multirow{3}{*}{ جوهرية } & \multirow[t]{3}{*}{$\cdot .11$} & \multirow{3}{*}{$\begin{array}{c}1.19 \\
1\end{array}$} & 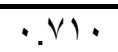 & $r$ & T.ITI & بين الفئات & \multirow{3}{*}{ العمر } \\
\hline & & &. .094 & roT & $101.17 \varepsilon$ & داخل الفئات & \\
\hline & & & & roq & 104.990 & التباين الكلي & \\
\hline \multirow{3}{*}{ جوهرية } & \multirow[t]{3}{*}{ 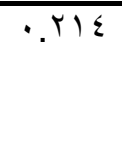 } & \multirow{3}{*}{$\begin{array}{l}1.0 . \\
\varepsilon\end{array}$} & $\therefore \wedge 19$ & $r$ & T.77V & بين الفئات & \multirow{3}{*}{ العؤهل } \\
\hline & & &. .091 & roT & $101 . \mathrm{KK}$ & داخل الفئات & \\
\hline & & & & roq & 104.990 & التباين الكلي & \\
\hline \multirow{3}{*}{ جوهرية } & \multirow[t]{3}{*}{$\cdot$. TIV } & \multirow{3}{*}{1.29} & $\cdot . \wedge \wedge \mathrm{r}$ & $r$ & $r . T \leqslant 0$ & بين الفئات & \multirow{3}{*}{ سنوات } \\
\hline & & &. .091 & ror & 101.10. & داخل الفئات & \\
\hline & & & & roq & 104.990 & التباين الكلي & \\
\hline
\end{tabular}

$$
\text { يتضح من الجدول } 10 \text { ما يأتي: }
$$

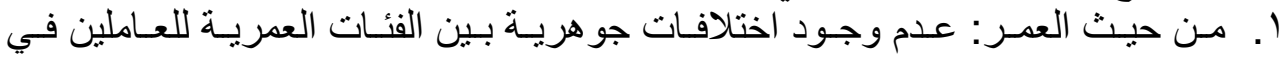
المستثفيات محل البحث من حيث مستوى رضاهم الوظيفي. 


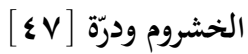

r'. مـن حيث المؤهل العلمي: عدم وجود اختلافـات جوهريـة بين فئـات المؤهل العلدي

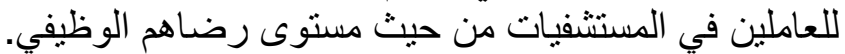

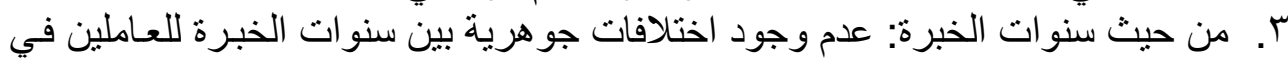

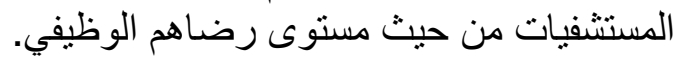

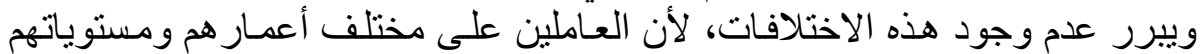

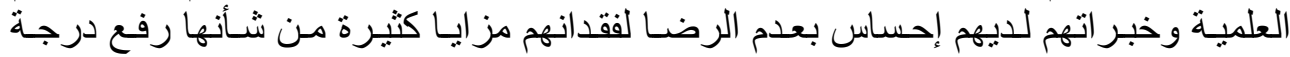

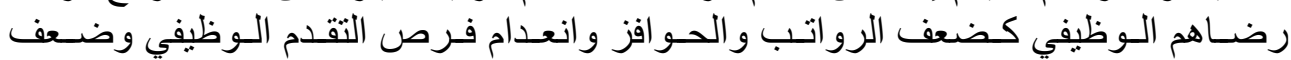
العلاقات بين العاملين و الإدارة.

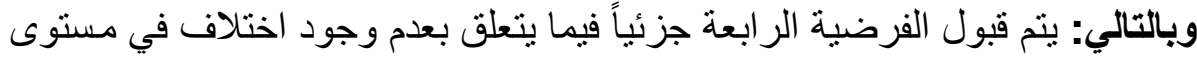

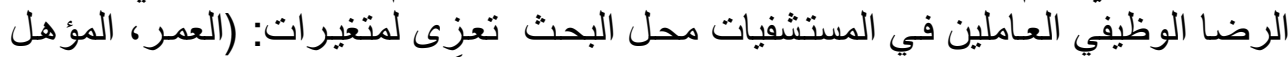

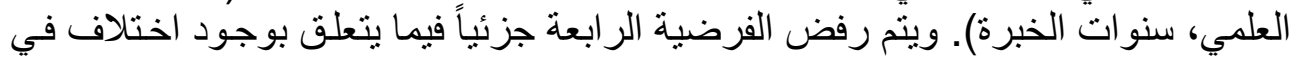
مستوى الرضا الوظيفي العاملين في المستشفيات محل البحث تعزى لمتغير: (النوع).

اختبار الفرضية الخامسة

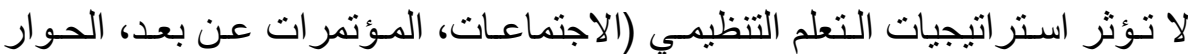

الاستر اتيجي، الفرق متعددة المهام، التعلم الفعال، الثبكات الرسمية، الثبكات غير الترنية الرسمية)

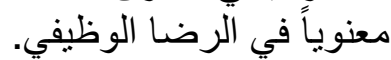
و لاختبار هذا الفرض تم استخدام تحليل الانحدار المنعدد بطريقة (Enter) والجدول

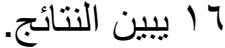

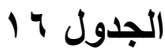

أنموذج الانحدار المتعدد لتأثير استراتيجيات التعلم التنظيمي في الرضا الوظيفي

\begin{tabular}{|c|c|c|c|c|c|c|}
\hline & & $\begin{array}{l}\text { 18) }= \\
\text { 0) }={ }^{2} R \\
\text { ) }=\end{array}$ & لـ الت التحديد الأنموذج المعيد المعدّل & مؤش معا & $\begin{array}{l}(.646)= \\
(.718)= \\
(.133)=\end{array}$ & 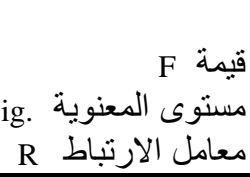 \\
\hline الإحصائية & المغنوية & المحسوبة & معامل الاتحدار & الخياري & الاتحدار & استراتيجيات التعلم \\
\hline & .000 & 13.949 & & .241 & 3.363 & الثنابت \\
\hline معنوية & .266 & -1.114 & -.104 & .080 & -.089 & الاجتماعات \\
\hline معنوية & .804 & -.249 & -.024 & .068 & -.017 & المؤتمرات عن بعد \\
\hline معنوية & .225 & 1.215 & .121 & .077 & . 094 & الحوار الاستر اتيجي \\
\hline معنوية & .245 & -1.165 & -.120 & .092 & -.107 & الفرق متعددة المهام \\
\hline معنوية & .390 & .862 & .087 & .083 & .071 & التعلم الفعال \\
\hline غير & .732 & .343 & .038 & .084 & .029 & الثبكات الرسمية \\
\hline
\end{tabular}




\begin{tabular}{|c|c|c|c|c|c|c|}
\hline شبكات غير الرسمية & & & & & & \\
\hline $\begin{array}{c}\text { غنوية } \\
\text { غعنوية }\end{array}$ & .739 & -.333 & -023 & .065 & -022 & .023 \\
\hline
\end{tabular}

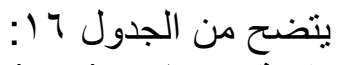

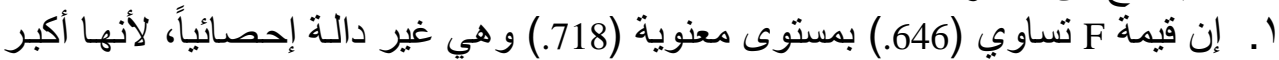

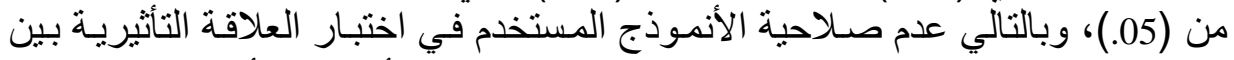

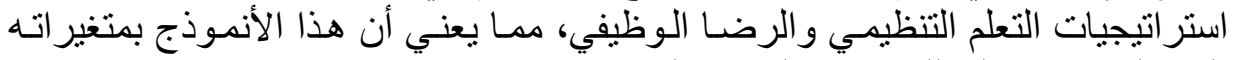

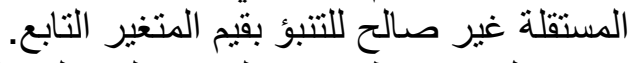

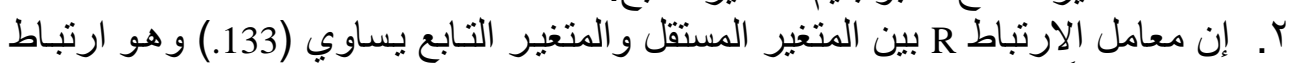

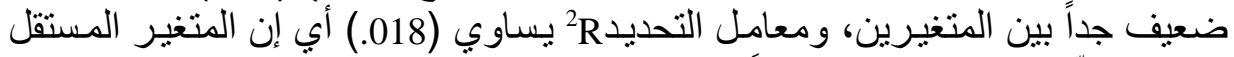

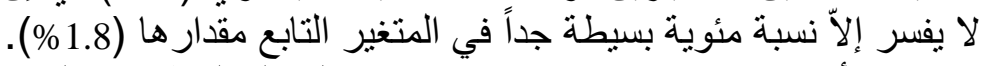

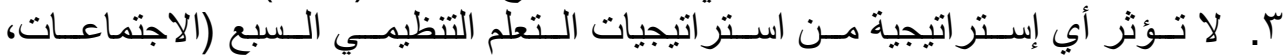

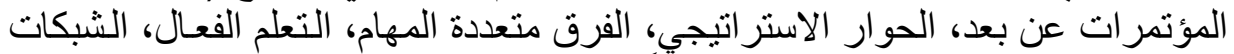

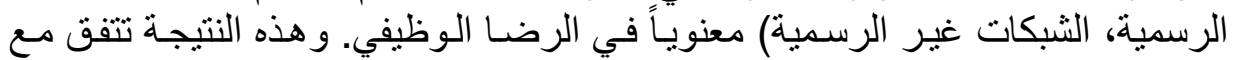

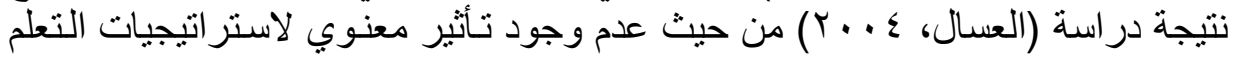

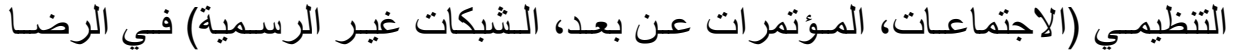

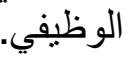

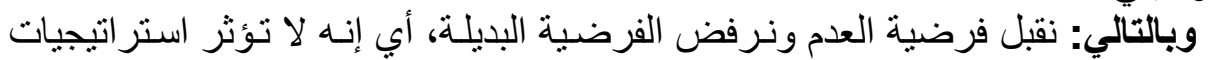

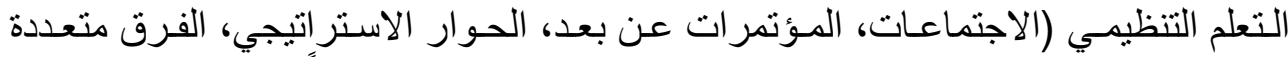

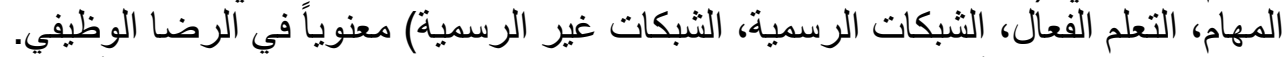

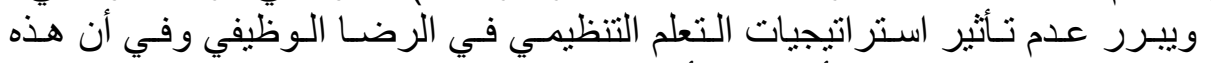

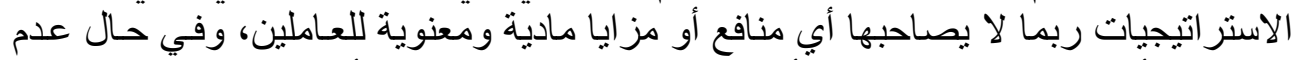

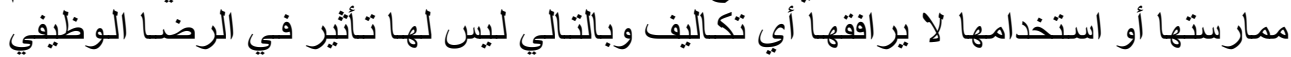

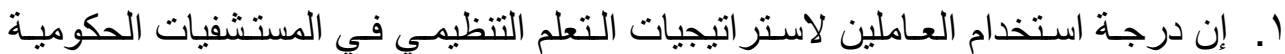

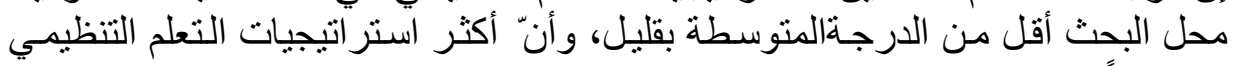

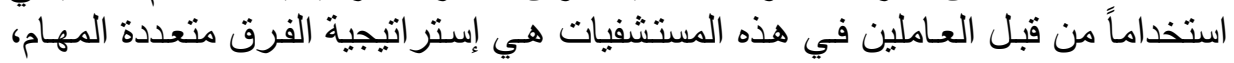

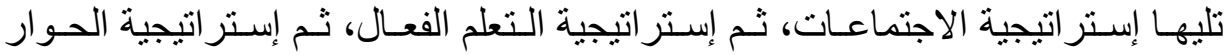

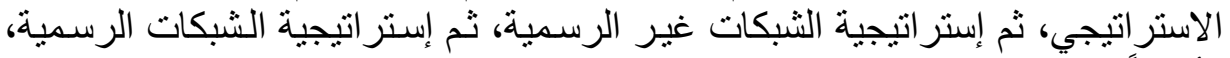

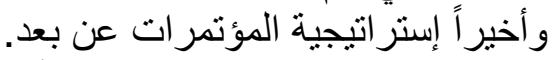

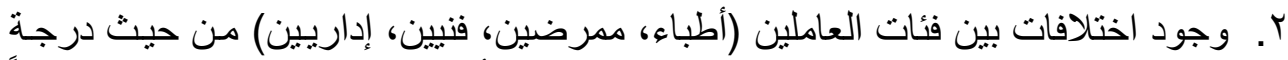

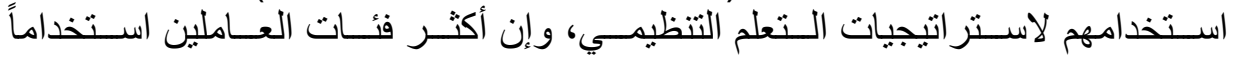

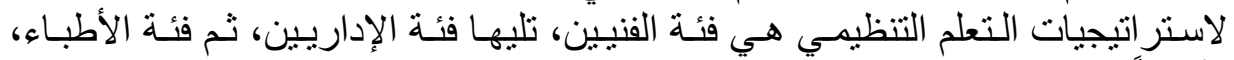

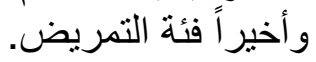

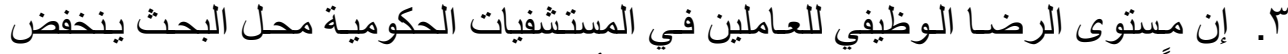

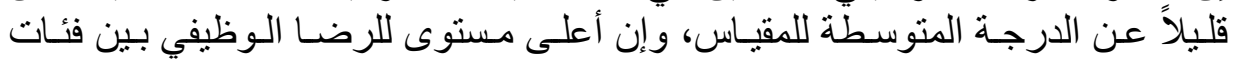




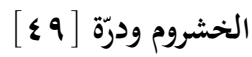

العاملين هو عند فئة الأطباء، يليها فئة الإداريين، ثم فئة الفنبين، وأخيراً فئة التمريض.

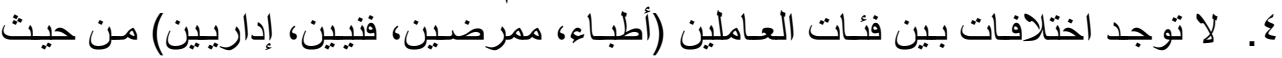

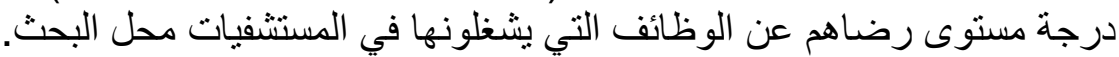

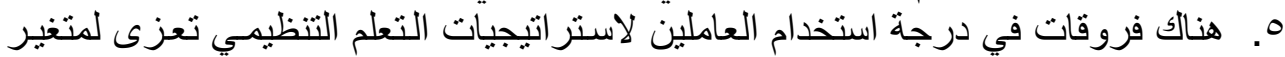

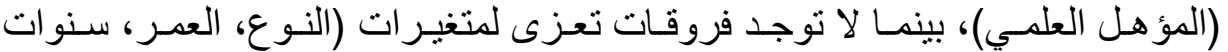

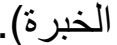
7. هنـالك فروقة).

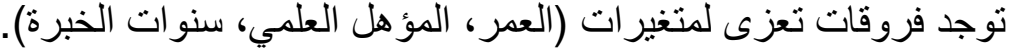

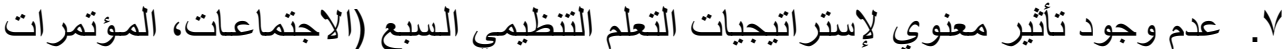

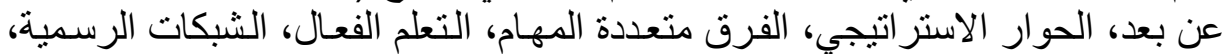
الثبكات غير الرسمية) في الرينا الرضا الوظيفي.

\section{التوصيات}

ا. الاعتناء بمفهوم استر اتيجيات التعلم التنظيمي و المنظمات المتعلمة لما تمثلكه هذه المفاهيم

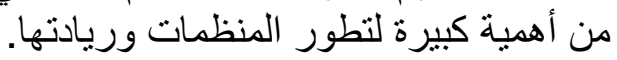
r. حث العاملين على زيادة درجة استخدامهم لاستر اتيجيات التعلم التظظيمي المتنوعة من خلال ما يأتي:

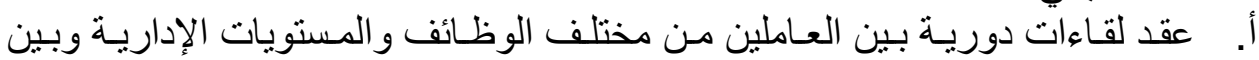

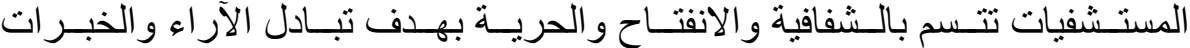

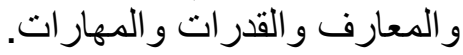

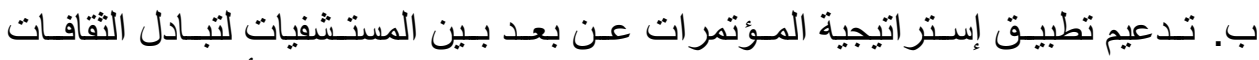

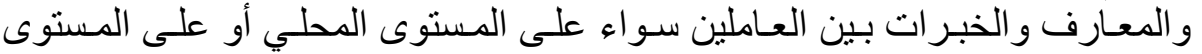

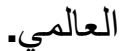

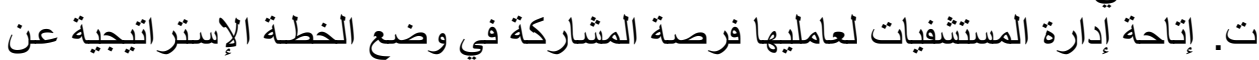

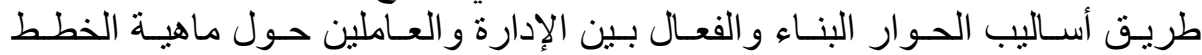
و البر امج و القرار ات التي سوف يتم التهاء التخاذها. ث. تشكيل فرق عمل متعددة المهام على نحو دائم لمعالجة المشكلات والتحديات التي التي

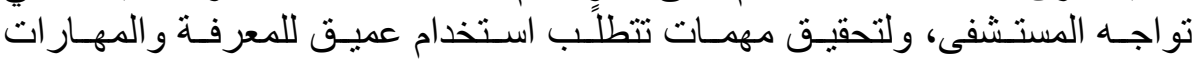
و الخبر ات بين أعضاء هذه الفرق.

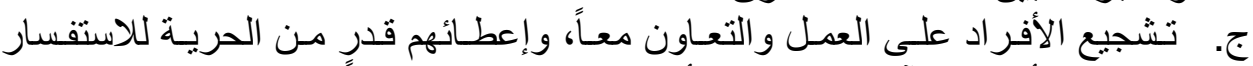
ومناقتة الأفكار والآراء، وتجريب أساليب عمل جديدة.

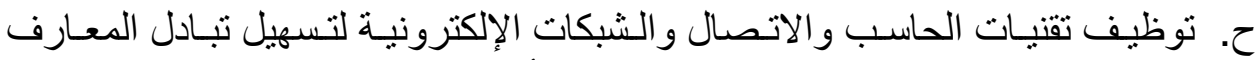

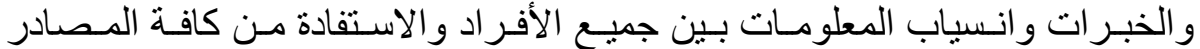

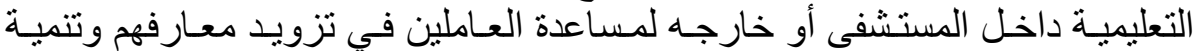
قدر اتهم ومهار اتهم. خ. استخدام العلاقات الخاصة والتار المعارف بين العاملين من مختلف الوظائف و المستويات

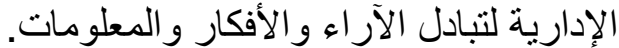

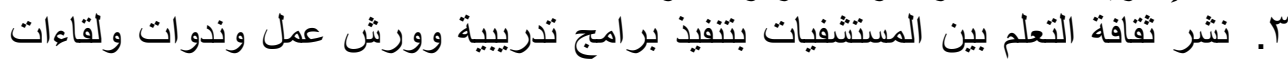

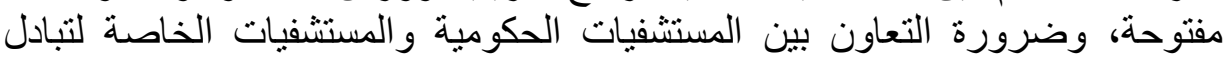
الخبر ات والمعارف و الاطلاع على آخر التطور ات والتحديثات داخل القطاع الصحي. 


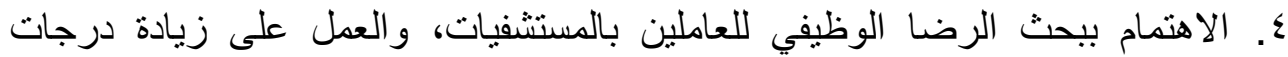

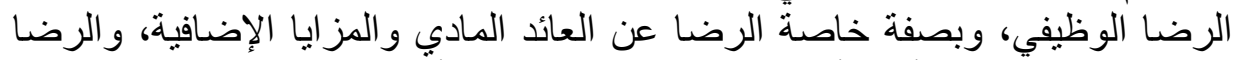

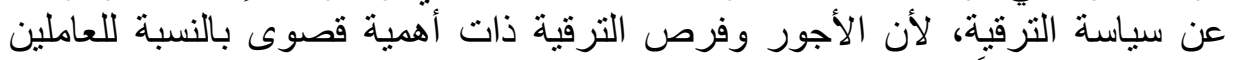

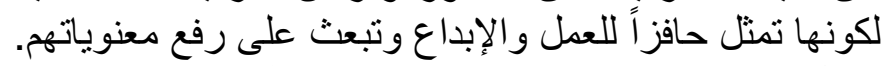

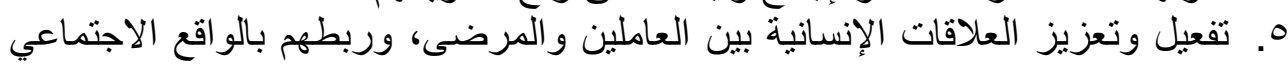

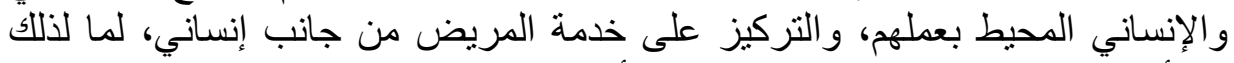

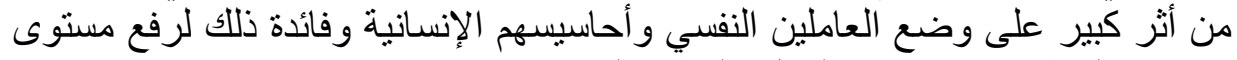

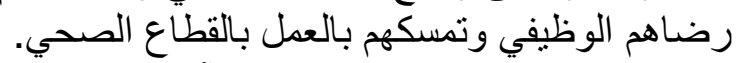

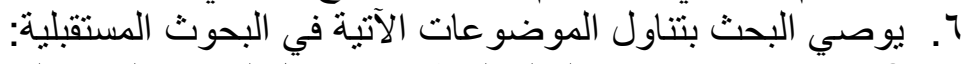

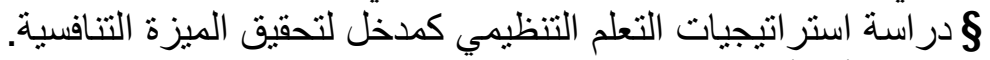

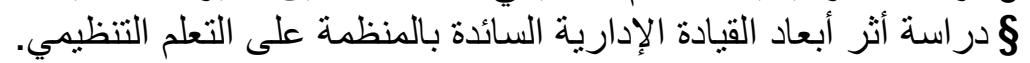

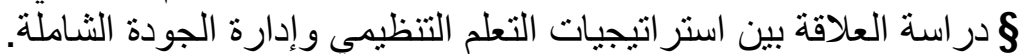

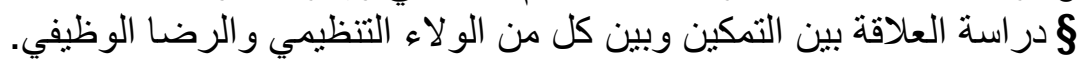

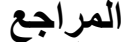 \\ أولاً- المراجع باللغة العربية الرية}

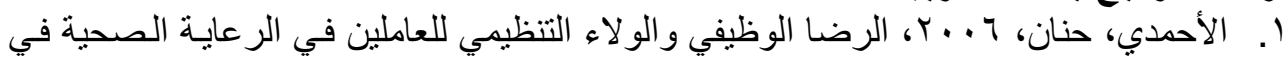

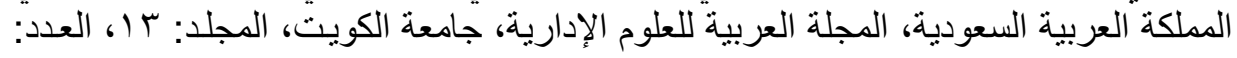

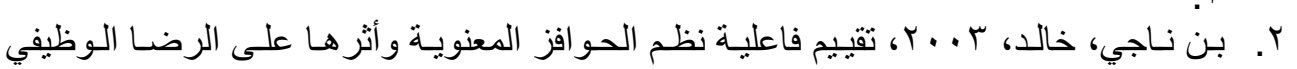

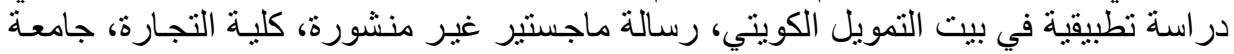
عين شمس.

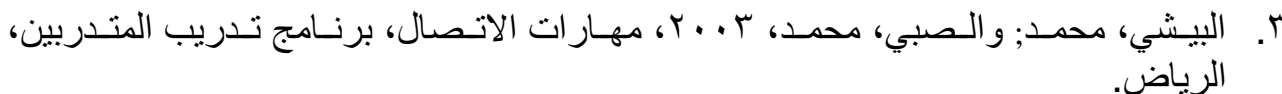

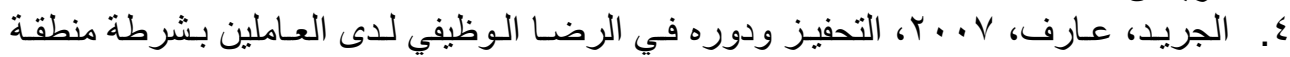

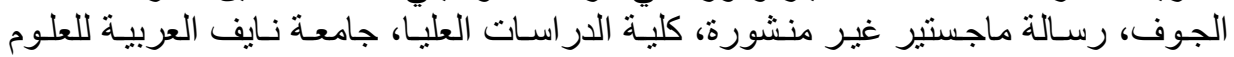
الأمنية.

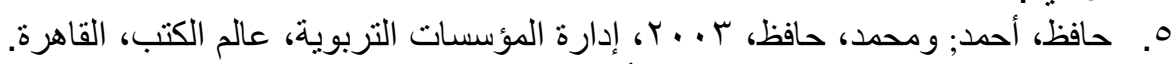

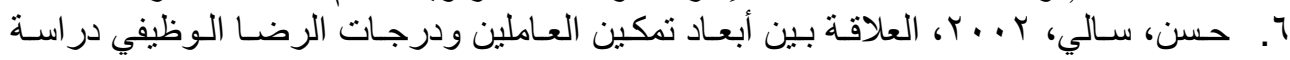

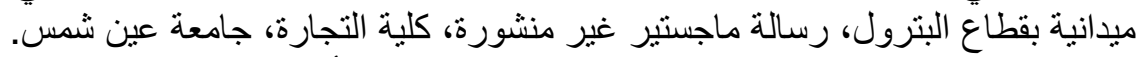

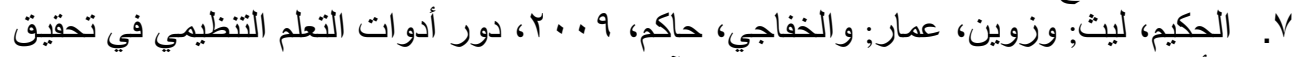

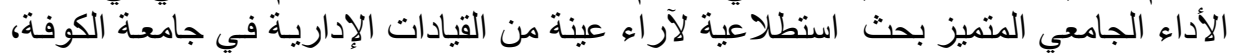

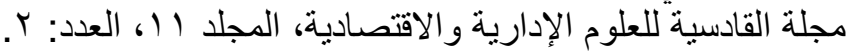

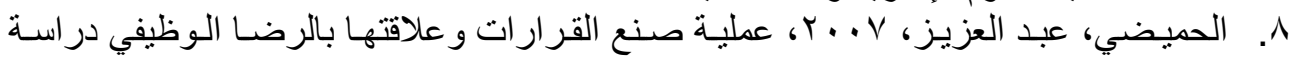

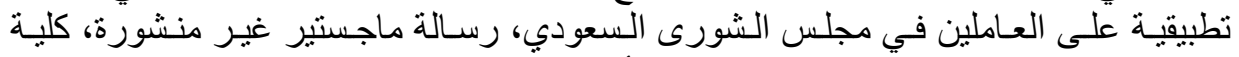

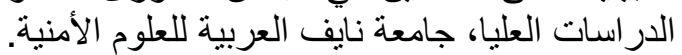

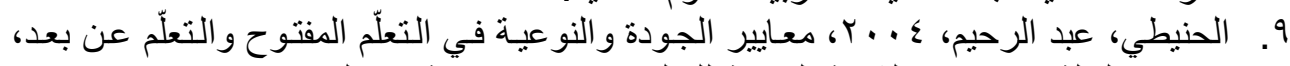

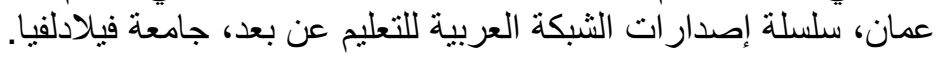

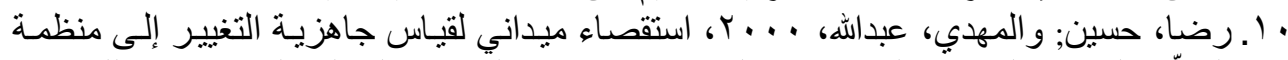

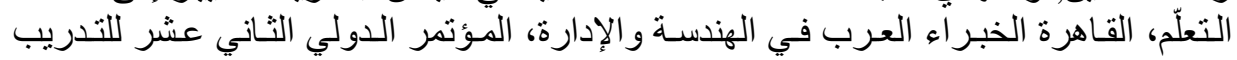
و التنمية الإدارية. 


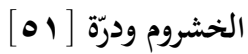

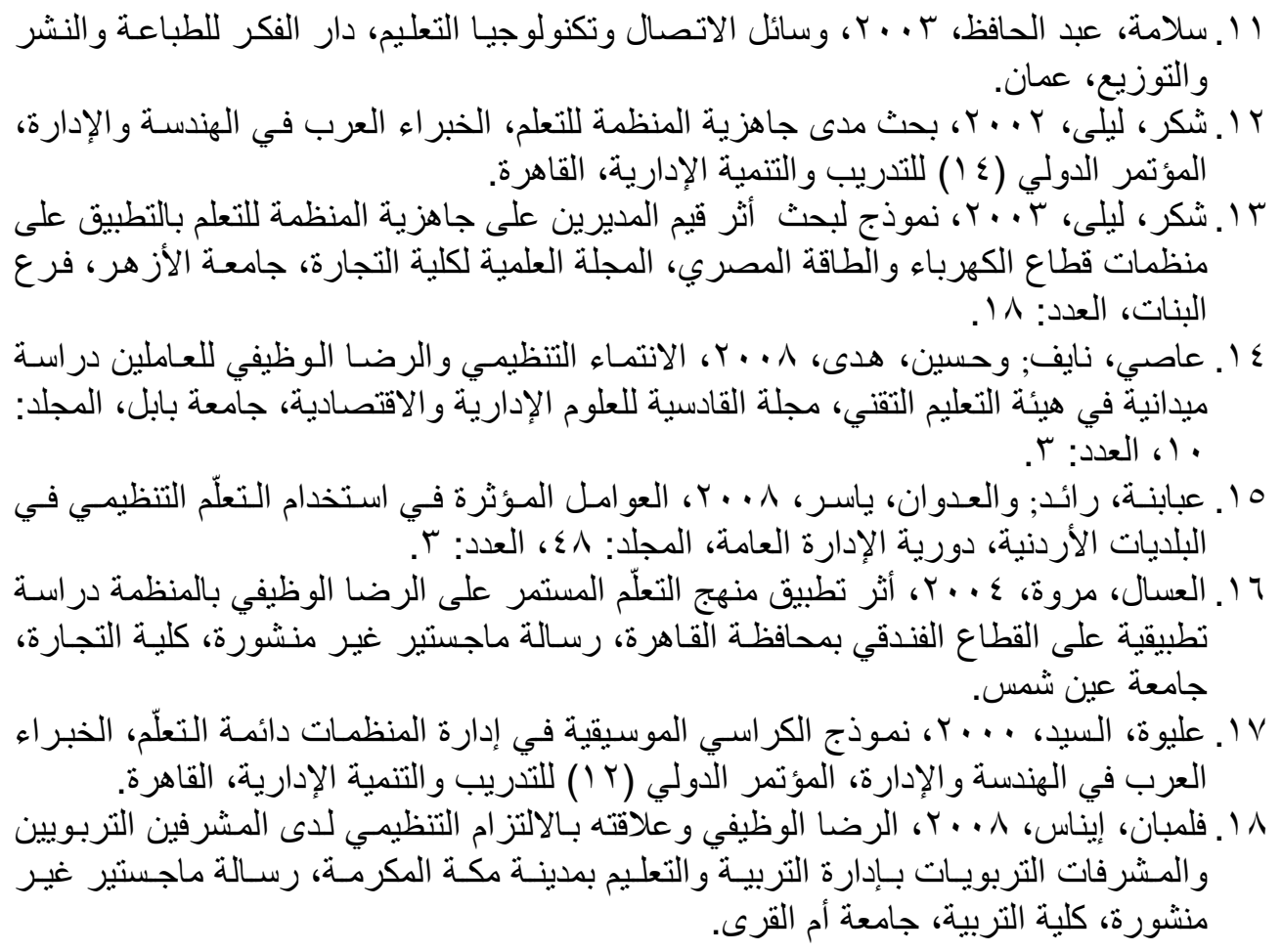

1. Arbel, G. 2009, Exploring The Contribution Of Guided Reflection To Organizational Learning Implications To Educational Organizations, Ph.D., North central University.

2. Checkering, R., Gamson, S. 2008, Diagnostic Tools For Learning Organizations, The Learning Organization, Vol. 8, No. 1.

3. Graham, C., Nafukho, F.2008, Exploring Organizational Learning Mechanisms In Small-Size Business Enterprises, New Horizons In Adult Education \& Human Resource Development, Vol. 22, Iss. 1.

4. Mazen, A. 2000, Transforming The Class Into A Learning Organization, Management Learning, Vol. 3, No. 2.

5. Mcdonnell, A., Gunnigle, P., Lavelle, J. 2008, Organizational Learning In Multinational Companies: Explaining Inter-Organizational Variation, University Of Limerick, Ireland.

6. Ogaard, T., Marnburg, E., Larsen, S. 2008, Perceptions Of Organizational Structure In The Hospitality Industry: Consequences For Commitment, Job Satisfaction And Perceived Performance, Tourism Management, No. 29.

7. Panayides, P. 2007, The Impact Of Organizational Learning On Relationship Orientation, Logistics Service Effectiveness And Performance, Industrial Marketing Management, New York: Vol. 36, Iss. 1.

8. Power, J., Waddell, D. 2004, The Link Between Self-Managed Work Teams And Learning Organizations Using Performance Indicators, The Learning Organization, Bradford, Vol. 11, Iss. 2.

9. Rabey, C. 2004, The Paradox Of Teamwork, Industrial \& Commercial Training, Vol. 35, No. 4.

10. Ssesanga, K. 2005, Job Satisfaction Of University Academics: Perspectives From Uganda. Higher Education, Vol. 50, Iss. 1. 
11. Wallach, E. 2001, Management Learning Groups: Continuous Quality Improvement For Managers, Journal Of Quality And Participation, Vol. 24, No. 2.

12. Yang, F., Chang, C. 2008, Emotional Labor, Job Satisfaction And Organizational Commitment Amongst Clinical Nurses: A Questionnaire Survey, International Journal Of Nursing Studies, Vol. 45. 